\title{
Hermenéutica teológica como ontología escatológica a la luz de la historia de las religiones según Wolfhart Pannenberg (1)
}

\section{LA HISTORIA: EL CONTEXTO INTERPRETATIVO TOTAL DE LA CIEN- CIA TEOLÓGICA (2)}

Pannenberg, a través de sus detallados análisis de la cultura secularizada moderna, afirma que esta, tanto en el ordenamiento práctico ordinario de la vida como, ante todo, en el acercamiento científico a la realidad, da por supuesta, por obvia, la ausencia objetiva del mundo de cualquier dimensión religiosa, o, si se quiere, trascendente. "Dios" no juega ningún rol positivo para ella. Dios deviene así una "hipótesis innecesaria" (Laplace) para la comprensión de aquel mundo que parecía estar a punto de entregar todos sus secretos al observador científico. "Autorrealización” es la palabra clave para caracterizar este abandono de lo religioso. Nuestro autor, a diferencia de otros teólogos contemporáneos, se niega a aceptar que este estado de cosas haya de ser tomado por la teología como un presupuesto prácticamente incuestionable (3). Como ejemplo podemos traer a colación los proyectos evangélicos señeros de G. Ebeling o de E. Jüngel; estos firmarían, por así decirlo, un armisticio "con la experiencia de la Modernidad, que se hace pasar por profana". Al dar por supuesto el hecho de que la experiencia religiosa haya desaparecido en la Edad Moderna, estos autores se verían obligados a caracterizar la conexión entre la experiencia de la fe y la experiencia habitual (pretendidamente no religiosa) como una "experiencia de la experiencia". "En lugar de eso -añade Pannenberg en el mismo lugar-, yo he intentado solucionar esa misma tarea [...] de modo que, partiendo de la estructura de sentido de la experiencia en general, describo la experiencia religiosa como una tematización del horizonte global de sentido implícito en toda experiencia, tematización hecha desde el punto de vista de la realidad constituyente del mundo en su totalidad y, por tanto, también de la

(1) Este artículo es resultado de una beca de investigación postodoctoral realizada en la Universidad de Tübingen (2002-2004) bajo el patrocinio del Intercambio Cultural Alemán-Latinoamericano (ICALA).

(2) Todas las citas en que no se hace referencia al nombre del autor son de Pannenberg.

(3) Cf. A. Dartigues, L'historie comme lieu théologique de la modernité, en: P. Gisel-P. Evrard (eds.), La théologie en postmodernité, Genève 1996, 113-188. 
identidad de la existencia humana" (4). El mencionado "punto de vista" es el que da a un determinado acercamiento a la historia su carácter "teológico" (5). Pannenberg cree tener motivos antropológicos suficientes para no aceptar el estado de las cosas al modo de los dos teólogos recién nombrados. Reseñemos, aunque solo sea brevísimamente, algunas de estas razones (6).

Pannenberg señala cómo el hecho de comprender al hombre se convirtió en una cuestión fundamental para la Edad Moderna, desde que la religión cristiana perdió su validez incuestionada como fundamento de la sociedad y de la conciencia cultural a raíz de la división religiosa de la cristiandad occidental. Con todo, en la filosofía de la Edad Moderna temprana la antropología constituyó, al menos en principio, un mero punto de partida para reconstruir de una forma puramente filosófica, es decir, independientemente de las controversias entre las distintas confesiones, el concepto de mundo sobre la idea de Dios. Fue solo en la reacción contra Hegel como la fundamentación de la conciencia filosófica sobre la antropología alcanzó un nuevo y afilado cuño, orientado al primado de lo objetivo y de rasgos marcadamente contrarios al primado de la idea de Dios. En esta forma agudizada, el giro antropológico sigue constituyendo la base de la conciencia filosófica de nuestros días: "Después de Hegel, el ser humano se convirtió, pues, en la cuestión central de la filosofía en un sentido nuevo y radical" (7). Es este un hecho que en nada cambia, señala nuestro autor, el que sobre esta base se haya llegado a justificar la religiosidad del hombre como una cuestión específica e irrenunciable de la forma humana de existencia, ya sea en el pensamiento de Max Scheler, la antropología de Helmut Plessner y Arnold Gehlen, o la filosofía existencial de Karl Jaspers y Henri Bergson.

Nuestro autor subraya con vehemencia, que en la actualidad, también la teología cristiana está obligada a tomar la antropología como base a la hora de probar la validez universal de la fe cristiana, aunque dicha base no es suficiente para llegar a cerciorarse de la verdad de la idea cristiana de Dios y de la revelación. De querer afirmarse la verdad del Dios cristiano en la actualidad, es indispensable que el mundo y la historia puedan cuando menos concebirse como obra y creación suya (8). Ahora bien, la experiencia del mundo que los saberes provenientes -como fuentes no primarias- de las ciencias de la naturaleza y del hombre encierran y ofrecen ha de ser "apropiada" por el saber específicamente teológico, el proveniente de la revelación. Nuestro autor distingue continuamente y por principio los dos tipos de

(4) Antwort auf Sauters Überlegungen, Evangelische Theologie 40 (1980), 180. Para esta temática cf. M. Dumas, Expérience religieuse et foi chrétiene chez Wolfhart Pannenberg, Revue de Théologie et de Philosophie 135 (2003), 313-327.

(5) Cf. Erwägungen zu einer Theologie der Religionsgeschichte, en: Grundfragen systematischer Theologie, Gesammelte Aufsätze, vol. 1, Göttingen ${ }^{3} 1979$, 256.290. Ver además las pertinentes reflexiones de J. A. Martínez Camino sobre las diferencias entre el planteo de Pannenberg y el de Jüngel, sobre todo a través del análisis del tratamiento que hace el primero al problema de la fe en el tercer volumen de su Teología Sistemática, La fe, un modo específico de conocer, en: C. Izquierdo (ed.), Teología fundamental. Temas y propuestas para el nuevo mileno, Bilbao 1999, 323ss.

(6) Para esta temática cf. sobre todo Anthropologie in theologischer Perspektive, Göttingen 1983 (Antropología en perspectiva teológica, Salamanca 1993).

(7) Theologie und Philosophie. Ihr Verhältnis im Lichte ihrer gemeinsamen Geschichte, Göttingen 1996, 300 (Una historia de la filosofía desde la idea de Dios, Salamanca 2001).

(8) Cf. Systematische Theologie, vol. 2, Göttingen 1993, 15-187 (Teología Sistemática, vol. 2, Madrid 1996). 
saber: el científico y el teológico. Al mismo tiempo insiste en que la integración diferenciada (y crítica) de ambos resulta imprescindible si se quiere dar cuenta conceptualmente de que el mundo experimentado por el hombre es el mismo mundo creado (y redimido) por Dios, por lo que se hace necesario considerar la doctrina de la creación en lo que respecta al "mundo mismo para interpretarlo como creación del Dios trinitario [...]. Solo en la medida en que pueda entenderse este mundo como creación del Dios bíblico, y el mismo Dios como Creador de este mundo, se podrá sostener fundadamente la verdad de la fe en su divinidad única [...] solo desde este presupuesto puede interpretarse la historia de Jesucristo como reconciliación del mundo por el único Dios verdadero; solo así acontece el anuncio y la misión de la Iglesia en obediencia a este único y verdadero Dios, y puede fundarse la esperanza cristiana en el futuro solo en El [...] la teología no puede renunciar a presentar el mundo natural y el de la historia humana como creación de Dios, y además con la pretensión de que solo así se capta la auténtica esencia de este mundo [...]. La renuncia a sostener que el mundo descrito por las ciencias es el mundo de Dios, significa renunciar a la justificación conceptual de la fe en la divinidad del Dios de la Biblia. Tal justificación no puede sustituirse remitiendo la fe en la creación a la subjetividad como expresión del propio sentimiento de dependencia" (9). Tarea de la teología sistemática es, según nuestro autor, mostrar siempre de nuevo esta "convergencia".

Pero el hombre forma parte del mundo y de la historia del mundo, por lo que la antropología es la cuestión primera y más próxima, y es con referencia a ella que se ha de probar la validez universal de la fe en Dios. Esto constituye para nuestro autor, si tomamos por ejemplo la arquitectura de su Teología sistemática, los "prolegómenos" del quehacer teológico. Si Feuerbach -el "padre de la iglesia del ateísmo" (10) - tiene razón y la fe en Dios no forma parte de la naturaleza del ser humano, sino que la religión tiene su nacimiento en una mala comprensión de aquella por el hombre en la forma de una fantasmática duplicación de su propia conciencia ("antropoteísmo" como le llama Feuerbach a su ateísmo), huelga seguir preguntándose por la verdad de la comprensión religiosa de Dios y, como consecuencia, también del cristianismo. Hay aquí un fallo anticipado con respecto a la verdad de la teología cristiana, aunque este no constituya ni mucho menos un juicio definitivo sobre la aspiración a la verdad de la fe cristiana. Pero frente a un segmento de la teología evangélica contemporánea, ya no es suficiente con argumentar, como Schleiermacher en los Discursos, que la religión posee "una provincia propia" en el ánimo, pues esta declaración, de dejarse relativizar psicológicamente en el sentido de Feuerbach, diría ya bien poco. Aquí se podría hablar con H.-J. Braun a propósito de este filósofo, que "la fe no se basa en razones suficientes, como se podría pensar en una filosofía de la religión de talante racional, sino de deseos suficientes" (11). En este sentido, Hegel tenía razón cuando criticaba el subjetivismo de la experiencia

(9) Ibíd., 77-78; cf. Glaube, Vernunft und die Zukunft des Christentums. Ein Gespräch mit Wolfhart Pannenberg, Edith Stein Jahrbuch 5 (1999), 27 ss.

(10) Cf. Der Kirchenvater des Atheismus, Deutsches Allgemeines Sonntagsblatt 37 (10-9-1972), 12.

(11) Stadien und Strukturen Feuerbachscher Religionskritik, en: H.-J. Braun et al (ed.), Ludwig Feuerbach und die Philosophie der Zukunft, Berlín 1990, 110. 
schleiermacheriana de Dios. El concepto schleiermacheriano de la intuición religiosa de Dios debe interpretarse cartesianamente -a partir de la tercera Meditacióncomo el primado de lo infinito sobre -y en - toda aprehensión de lo finito, para así poner de relieve el núcleo objetivo todavía válido de la argumentación de Schleiermacher (12). Pero, a su vez, el examen cartesiano de la naturaleza de la conciencia humana está necesitado de un fundamento más amplio, el cual vendría procurado por la comprensión del modo de ser específico del hombre como ser viviente. Este fundamento está dado, como señala Pannenberg, en la definición scheleriana y plessneriana del hombre como un ser "abierto al mundo" y determinado excéntricamente tanto en lo tocante a su modo específico de comportarse como en lo relativo al substrato corpóreo de dicho comportamiento. De este modo, nuestro autor accede a una base antropológica que da cuenta, a la vez que reserva un espacio propio a cada uno de ellos, tanto del punto de vista cartesiano de que toda percepción finita está condicionada por una intuición del infinito anterior a ella, como del concepto schleiermacheriano de intuición religiosa. A ello se añadirá a continuación la tesis hegeliana, fundamental para Pannenberg, de lo ineludible de que el yo finito que cifra todo sobre sí mismo haga de sí un absoluto. En conjunto, de este modo Pannenberg dispone de una base fenoménica lo suficientemente amplia, además de profundamente enraizada en la historia de la filosofía reciente, como para poder enfrentarse con buenos argumentos a aquella interpretación que niega que la temática religiosa forme parte constitutiva de la naturaleza humana o dicho de otra manera, que sospecha (en el sentido de la "hermenéutica de la sospecha") que aquella no sea más que una ilusión, una proyección. O, en lenguaje de Feuerbach, que la "imaginación" es el "órgano y la esencia originaria de la religión”, y esta a su vez, un "sueño del espíritu humano".

Los estudios hermenéuticos de Pannenberg, objeto directo de nuestra presentación en este Seminario, le confirman en la convicción de que la religiosa es una dimensión inexpurgable de la realidad. Es la convicción que alimenta su concepción de la teología como "ciencia de Dios" en el marco de una "teología de las religiones".

Partiendo de la idea de que lo divino pertenece inextrañablemente al ser del hombre, la constatación de que la historia de la humanidad es la historia de la(s) religión(es) se convierte en algo más que en una afirmación arqueológica sobre el pasado. Entonces se hace inevitable la pregunta por el contenido de verdad de las religiones hoy. ¿Sigue siendo la historia del hombre una historia religiosa a pesar de las apariencias contrarias? ¿En qué medida responde a la realidad del mundo y del hombre la pretensión de las religiones de ofrecer la automanifestación del fundamento último y la base del sentido de todo ser?

Pannenberg cree que ya es hora de que el pensamiento secular se plantee la cuestión de si no será él el que se ha dejado deslumbrar por la ilusión de la total autonomía del mundo. Para una teología concebida, como la suya, a la manera de "teología de las religiones", sería más que suficiente que dicho planteamiento se

(12) Cf. Religion und Metaphysik, en: Beiträge zur Systematischen Theologie. Philosophie, Religion, Offenbarung, vol. 1, Göttingen 1999, 53ss; ver el llamado a repensar la temática del infinito que realiza A. Torres Queiruga en su sugerente libro, Fin del cristianismo premoderno, Santander 2000, 28 ss. 
realizase a modo de hipótesis, porque también ella trata las tesis mantenidas por los diversos credos en torno a Dios como hipótesis que la historia (religiosa) misma habrá de ir mostrando como más o menos adecuadas a la realidad.

De aquí que "la historia [sea] el más amplio horizonte de la teología cristiana" (13). Esta conocida afirmación, que encabezaba el artículo programático de 1959 Acontecer salvífico e historia, aparece hoy como el centro de la teología de Pannenberg. La historia es el horizonte más abarcante de la teología porque ella es el campo en el que se decide sobre la realidad de Dios como el poder determinante de todo o el "poder del futuro" (esta última definición es importante para comprender el andamiaje de la teología de Pannenberg, pues el futuro es la forma de ser de Dios (14), quien tiene por consiguiente que acreditarse aun en la experiencia de la humanidad, pues solo al final de la historia concluirán los debates sobre Dios). En ella se habrá de ir mostrando hasta qué punto una determinada concepción tradicional de la divinidad responde en realidad a su pretensión de relevancia universal. Es cierto que su ininterrumpido fluir no permitiría hacerse un juicio totalmente acabado sobre la verdad de las diversas religiones (o sucedáneos) que concurren en su devenir. Pero sí que sería posible hacer juicios hipotéticos, en torno al grado de adecuación de una u otra concepción de lo divino de acuerdo con su mayor o menor capacidad de iluminar, de dar sentido, a la experiencia de cada pueblo y de cada época.

Pannenberg ha señalado los conceptos que él juzga básicos para el desarrollo de una teología de la historia capaz de formular los juicios a los que nos acabamos de referir. Son las ideas teológicas de "pueblo de Dios", "actuación de Dios" y, en particular, "elección", "juicio" y "alianza". Una lectura de la historia hecha con su ayuda habría de permitir enjuiciar fenómenos históricos concretos en su relación con el Dios bíblico. Por ejemplo, si el ateísmo moderno testimonia también el poder de Dios bajo la forma de sus consecuencias negativas (al modo por ejemplo de Nietzsche en La gaya ciencia), que habría que interpretar como "juicio" de Dios; o si, desde otro punto de vista, el descubrimiento progresivo del valor de la persona humana (libre) habla en favor de la fuerza del Dios, cuya revelación histórica lo habría ido haciendo posible como muestra de su "elección".

No es casual que los conceptos básicos de la teología de la historia sean de origen bíblico. Pero recurrir a ellos no es tampoco una decisión "dogmática", no justificada. Cualquier observador de la historia de las religiones podría ver que es precisamente la religión de Israel y, con ella, la cristiana, la que ha hecho de la historia su propio tema. El Dios bíblico sería, en efecto, el primero que habría hecho del devenir histórico concreto el lugar de su automanifestación. De aquí que para la teología la historia no sea solo el horizonte más abarcante, sino también, por así decir, el "principio de individuación" (15) de la divinidad. La verdad de una determinada representación religiosa de Dios, es decir, la realidad de Dios en cuanto tal,

(13) Heilsgeschehen und Geschichte, en: Grundfragen systematischer Theologie, Gesammelte Aufsätze, vol. 1, 22 (Acontecer salvífico e historia, en: Cuestiones fundamentales de teología sistemática, Salamanca 1976, 211-276); cf. Eternity, Time and the Trinitarian God, Dialog 39 (2000), 9-14.

(14) Cf. Der Gott der Hoffnung, en: Grundfragen systematischer Theologie, Gesammelte Aufsätze, vol. 1, 387-398, aquí 393, "Zukunft als Seinsweise Gottes" (El Dios de la esperanza, en: Cuestiones fundamentales, 197-210).

(15) Anthropologie in theologischer Perspektive, 472.5 
no se decide ni en una historia de las religiones "neutral" (G. van der Leeuw) ni en una filosofía general de la religión. Las reflexiones de estas ciencias habrán ciertamente de formar parte del discurso teológico que pretenda estar hoy a la altura de los tiempos. Pero una "mostración" de Dios solo es posible en el contexto de la reflexión sobre su automanifestación histórica.

Ahora bien, llegado este punto de nuestra argumentación se presentan dos temáticas interconectadas que aquí solo podemos señalar, que son relevantes en la estructura teológica pannenbergiana y que están presupuestas en los análisis de la hermenéutica de nuestro autor. La primera hace relación a que a la consideración concreta y "empírica" de la historia de las religiones habrá de preceder la elucidación más abstracta de las ideas mismas de "Dios" y de "religión". Esa sería la tarea de la filosofía de la religión, que se habrá de desarrollar hoy con los medios de la antropología: "De una teología de las religiones [...] forma parte, en primer lugar, una filosofía de la religión que desarrolla el concepto general de religión y que introduce, en ese marco, el concepto de Dios como la realidad que todo lo determina. Dada la situación del debate sobre estos temas en el contexto propio del pensamiento moderno, la filosofía de la religión a la que nos referimos necesitará, como base, una antropología general. Un ejemplo de cómo se puede llevar a cabo esta tarea es desarrollar el concepto de religión en conexión con la temática de la experiencia humana de sentido, concretamente, en referencia a la totalidad de sentido implícita en toda experiencia de sentido, la cual implica, por su parte, una realidad determinante de todo como unidad unificadora de esa misma totalidad de sentido" (16). La segunda se refiere a cómo descubre Pannenberg el lugar antropológico de estos conceptos teológicos básicos. Con respecto a esto último es necesario subrayar que la teología que nuestro autor elabora pretende ser una teología fundamental, ocupada en descubrir las potencialidades religiosas y teológicas de la antropología. No es su intención sin embargo efectuar una reducción de la teología a la antropología ni proponer una nueva prueba de la existencia de Dios de corte antropológico. Pannenberg realiza este recorrido antendiendo básicamente a siete clases de experiencia: la apertura al mundo, la creatividad, la confianza, la esperanza, la identidad, la sociabilidad y la historicidad. Nos queda ahora por referir cómo los entronca con la problemática hermenéutica en su concepción de la teología como ciencia del Dios que se manifiesta en la historia religiosa de la humanidad (17). En el próximo punto nos acercaremos (2), pues, a la cuestión del sentido y de su aprehensión lingüística con el fin de descubrir la base de la teoría hermenéutica de nuestro autor. Para Pannenberg es importante la constatación de que ya aquí aparecería, al menos de modo implícito, la idea de Dios. La explicitación de la interrelación existente entre hermenéutica e idea de Dios precederá por ello a la revisión de los orígenes materiales de la hermenéutica teológica de la historia en la religión bíblica.

(16) Wissenschaftstheorie und Theologie, Frankfurt 1973, 370-371 (Teoría de la ciencia y teología, Madrid 1981).

(17) Cf. G. Wenz, Wolfhart Pannenbergs Systematische Theologie. Ein einführender Bericht, Göttingen 2003, aquí 10-11; ver además, T. Kleffmann, Systematische Theologie - zwischen Philosophie und historische Wissenschaft, Neue Zeitschrift für systematische Theologie und Religionsphilosophie 46 (2004), 207-225. 
La estructura de nuestra presentación, que acabamos de introducir en este primer punto, responde a la descripción que Pannenberg mismo hace de su proyecto hermenéutico: "Por ejemplo, yo mismo he intentado mostrar, estimulado por la hermenéutica de H. G. Gadamer, que la tarea de la interpretación, en cuanto fusión de los horizontes de comprensión del autor y del intérprete, presupone la totalidad de la historia como último marco de referencia. Después, continuando esa misma investigación, he puesto de relieve la idea de Dilthey de que toda experiencia particular de sentido implica una totalidad de sentido, la cual, puesto que el sentido experimentado se halla anclado en la historicidad de la situación en la que se hace la experiencia, no nos es accesible más que en la anticipación de un futuro todavía por aparecer. Aquí, a diferencia de lo que sucede en la hermenéutica de Ebeling, presenté la totalidad de sentido, implícita tanto en la labor hermenéutica como en cada experiencia individual de sentido, como el punto de vista bajo el cual surge la interrelación entre idea de Dios y temática hermenéutica. Puesto que hablar de Dios como la realidad determinante de todas las cosas está en correspondencia con el tema de la totalidad, parece que la conexión se establece aquí de modo menos forzado y sin el momento de positividad que se encuentra en la referencia de Ebeling al poder pleno de Jesús. Además, la totalidad de sentido implícita en la experiencia hermenéutica solo se puede describir como la totalidad de una historia y, por tanto, permanece en el ámbito de esa realidad que el Dios bíblico ha desvelado como historia. De este modo, la problemática hermenéutica de la traducción del entonces al ahora se nos presenta como algo no ajeno a la tradición de la fe bíblica, sino incluido ya en la comprensión bíblica de Dios, como algo inmerso en el camino de la historia hacia la automanifestación escatológica del Dios bíblico" (18).

\section{EL LENGUAJE COMO POSIBILIDAD DE EXPRESAR LA ESTRUCTURA DE SENTIDO DE LO EXISTENTE: LA PLUSVALÍA DE LO NOMBRADO COMO HUELLA DE LA TOTALIDAD}

\section{1. ¿Comprensión contextual o creación lingüística?: hacia una búsqueda del sentido}

En la línea de la filosofía moderna y contemporánea, Pannenberg señala que el hombre puede muy bien ser definido como el ser del lenguaje (por ejemplo Heidegger, en De camino al habla). Este es el medio en el que el mundo adquiere para nuestro autor un sentido. La aprehensión lingüística del sentido está así en el centro del interés de nuestro autor, incluso por partida doble.

Por un lado ve en un fenómeno antropológico tan característico como es este un caso privilegiado para el desarrollo de una filosofía de la religión, según él, imprescindible hoy para al menos introducir el concepto de Dios. A través de una minuciosa y ágil discusión con destacados representantes del positivismo lógico, del racionalismo crítico, de la filosofía hermenéutica, de la teoría habermasiana de la

(18) Wissenschaftstheorie, 286s. Cf. J. A. Martínez Camino, Recibir la libertad. Dos propuestas de fundamentación de la teología en la modernidad: W. Pannenberg y E. Jüngel, Madrid 1992. 
acción comunicativa y de otras "teorías de la acción" (19), Pannenberg perfila su concepto de la "totalidad de sentido", para él, uno de los apoyos antropológicos de la idea de Dios.

Por otro lado, el análisis de la temática del sentido y del lenguaje resulta indispensable como primer paso de la aclaración de los problemas hermenéuticos que plantea el acercamiento teológico a las religiones históricas y en particular a la revelación cristiana. Es sobre este segundo aspecto sobre el que nos vamos a centrar ahora comenzando por una delimitación del uso que Pannenberg hace de la idea de sentido. Sobre el primero volveremos en el próximo punto.

En un primer momento, Pannenberg habla de sentido en el contexto de la lógica del lenguaje. Hay que tenerlo muy presente para no tomar unívoca y equivocadamente su expresión "estructura de sentido de la realidad" como equivalente de "la realidad tiene un sentido positivo" (20). No se trata todavía de ver si esto es o no es así, sino de analizar las condiciones que hacen del lenguaje el medio de la representación del sentido. Hay, pues, que distinguir entre un concepto formal de sentido y otro material o, podríamos decir, vital. En efecto, el fenómeno del lenguaje parece presuponer que la realidad es una "estructura de sentido", que es "sinnhaft". Pero eso no implica necesariamente que se trate de una realidad con sentido, "sinnvoll" (21). Por el contrario, la misma experiencia del sinsentido está en realidad posibilitada por ese modo de ser de la realidad que hace de ella un todo de sentido. De esta manera, para nuestro autor, el círculo de sentido es más amplio que el de lo que positivamente tiene sentido. Una estructuración de sentido la tiene incluso la experiencia de carencia de sentido, así como también la negación nihilista de que se pueda dar algo con sentido; así Sinnhaft sería la realidad en general, incluso la prelingüística; lo es igualmente el hombre como sistema individual, como subjetividad con identidad y capaz de experiencia. Todo ello habría que distinguirlo de la plenitud de sentido de contenido que tendría que ser puesta en relación con la posible realidad de un sentido global positivo sustentador del conjunto de lo real. La decisión sobre esta posible realidad quedaría reservada a la teología de la historia. Tanto la experiencia positiva de sentido como la de sinsentido son así posibles porque hay una realidad constituida como un todo de relaciones entre las diversas partes que lo integran. "Sentido" hace, en primer lugar, referencia a estas interconexiones en el todo (22) (el "sentido" aquí aludido surge para nuestro autor de la relación de las partes con el todo en los más diversos contextos: en el de la vida, como la plantea Dilthey, en el del discurso y en el sociocultural, entre otros; la relación de las partes en y con el todo puede ser tratada a nivel temporal individual o también general atemporal (23)). Se trata de un "fenómeno primordial", "fundamentalmente dado", al que ciertamente no tendríamos acceso sin nuestro lenguaje. Pero es un fenómeno previo al lenguaje mismo. No es en modo alguno una creación linguística.

(19) Cf. la primera parte de Wissenschaftstheorie.

(20) Cf. Antwort auf Sauters, 172.

(21) Esta es una problemática clave de la discusión hermenéutica actual en la filosofía, cf. M. Jung, Hermeneutik, Hamburg 2002, sobre todo 12ss.

(22) Cf. Wissenschaftstheorie, $135 \mathrm{ss}$.

(23) Cf. ibíd., 135ss. 156. 
En la discusión en torno al concepto de sentido a la que, en el fondo, dedica la primera parte de su obra programática Teoría de la ciencia y teología, Pannenberg se inclina por una comprensión contextual del mismo. Al optar así trata de moverse entre el polo de una concepción del sentido dominantemente referencial, representada ante todo por el positivismo lógico o el racionalismo crítico, y el polo de la predominantemente intencional, cuyos representantes estarían en las diversas teorías de la acción, desde M. Weber a J. Habermas.

En el concepto contextual de sentido, Pannenberg cree poder encontrar las bases para una concepción de la ciencia que rompa con el ya viejo dualismo que se ha establecido entre ciencias del espíritu y ciencias de la naturaleza. De este modo, el estudio que acabamos de mencionar trata de señalar el lugar que le correspondería a la teología en el panorama actual de las ciencias, no menos marcado por los positivismos que por las diversas teorías sociológicas de la acción.

Schleiermacher y, sobre todo, Dilthey han abierto caminos en esta dirección. Pannenberg recoge ante todo las ideas fundamentales del segundo introduciendo algunas correcciones inspiradas en la hermenéutica de Gadamer. De la filosofía del lenguaje y de la moderna teoría de la ciencia, particularmente de Popper, recibe impulsos que no podía esperar de ninguno de los anteriores. Piénsese en el enorme interés de nuestro autor por lo dicho, por las proposiciones, por la dimensión predicativa del lenguaje, en la que ve él un rasgo fundamentalísimo del mismo al que va unido su carácter hipotético. Por el contrario, en la tradición que arranca de Schleiermacher, Pannenberg encuentra subrayada la otra dimensión en la que se mueve el fenómeno del lenguaje: el horizonte indefinido de lo no dicho. Tratemos de seguir sintéticamente esta conformación del pensamiento hermenéutico de nuestro autor.

\subsection{Solo el final de la cadena nos retrotrae al sentido de cada uno de los eslabones: la influencia decisiva de Dilthey en Pannenberg en relación al "contexto de sentido" y la "totalidad".}

A la hora de señalar el lugar de procedencia de elementos centrales de su concepción hermenéutica, nuestro autor se remite a Dilthey (24). Lo que Pannenberg retendrá son dos aspectos efectivamente fundamentales para su propio pensamiento: la prioridad del todo en el proceso de comprensión de las partes y la historicidad de la experiencia del sentido.

Pannenberg ve el "mérito mayor" de Dilthey en su percepción de que el sentido brota de las circunstancias mismas de la vida y de que, por tanto, no es necesario "introducirlo" en ella (25). Más en concreto, el sentido procede del conjunto de la vida, de la unidad que ella forma. Este es el "leitmotiv de la lógica hermenéutica de Dilthey" (26): la comprensión de lo particular acontece en cada caso en el contexto del respectivo todo. En un primer momento, Dilthey había visto la fundamentación

(24) Pannenberg enjuicia su propia teología (entrevista), en: M. Fraijó, El sentido de la historia. Introducción al pensamiento de W. Pannenberg, Madrid 1986, 275.

(25) Cf. Sinnerfahrung, Religion und Gottesfrage, en: Beiträge zur Systematischen Theologie, vol. 1, 109.

(26) Wissenschaftstheorie, 66. 
de su tesis en la psicología del individuo: los diversos aspectos de la experiencia encontrarían su sentido en la "unidad vital", en "el sentimiento inmediato de nuestro ser indiviso" (27). A pesar de esta reducción subjetivista, Pannenberg observa que el planteamiento era ya entonces correcto, pues con las categorías de "todo" y "parte" se adquieren los elementos necesarios para una comprensión contextual de la cuestión del sentido que permitirá librarse de este y de otros subjetivismos.

Que el planteamiento era correcto se mostraría ya en que, al abandonar la perspectiva psicologizante, Dilthey no tuvo que abandonar también su "lógica hermenéutica". Lo que tuvo que hacer entonces fue pensar históricamente la relación entre "todo" y "parte". Cae mejor en la cuenta de que el lugar y el momento en el que acontece la experiencia de sentido es siempre diverso, provisional. Tanto las experiencias particulares como la percepción o el "sentimiento" del conjunto varían según los diversos puntos de observación en los que el devenir nos coloca. Solo el final de la vida nos proporcionaría el lugar desde el que hacer una experiencia definitiva y un criterio para juzgar las diversas experiencias particulares. Aquí nos encontramos con una idea clave de los últimos escritos de Dilthey, recurrente en toda la obra de Pannenberg a modo de continuo, que es que la unidad de la vida no es solo una categoría propia de un observar externo, o que tiene lugar desde fuera, sino algo que se hace inmediatamente presente en sus "vivencias" al sujeto de las mismas (28). Con el concepto de vivencia enlazan los conceptos de "significado" y "significación". Cada vivencia particular significa algo como parte de un todo, a través de su relación con el todo de la vida. Ahora bien, el valor de cada vivencia para el todo de la vida va cambiando con el tiempo a medida que esta transcurre, y así es como también se modifica su significado en nuestro recuerdo. Por ello, el significado que cada vivencia particular tiene en el curso de nuestra vida nunca está del todo definido, excepto al final: "Solo en el último momento de una vida puede extraerse el cálculo aproximado de su significado y, por eso, dicho cálculo solo puede aparecer tal cual es realmente al final de la vida o en alguien cuyas vivencias sean similares a las que compusieron esa vida que ahora termina" (29). "Uno tendría que esperar a que la vida llegase a su fin para poder abrazar con la vista, y esto solo en ese instante final, esa totalidad que permite saber cuál es la relación existente entre sus partes. Uno tendría que esperar a que la historia terminase para tener en sus manos todo el material necesario para saber por fin cuál es su significado" (30). Por otra parte, agrega Dilthey, en "la determinación del significado del pasado" influye también lo que "nosotros nos hemos marcado como meta de nuestro futuro", porque ese marcarse metas está relacionado con aquella parte del todo de la vida que queda todavía por transcurrir y, de este modo, con el todo mismo. Y, en definitiva, para comprender el sentido del conjunto de las vidas de los hombres, es el final de la historia el que tendría la llave. Pero como la historia no está nunca terminada ante nosotros, Dilthey cree que hay que conformarse con la relatividad de los diversos

(27) Cf. esta cita de Dilthey de Gesammelte Schriften, vol. I, 16 citada en Wissenschaftstheorie, 78.

(28) Cf. W. Dilthey, Gesammelte Schriften, vol. VII: Der Aufbau der geschichtlichen Welt in den Geisteswissenschaften, Göttingen ${ }^{8} 1992,229$.

(29) Ibíd., 237.

(30) Ibíd., 233; ver, Sinnerfahrung, Religion, Gottesfrage, 101-113; Systematische Theologie, vol. 3, Göttingen 1993, 648-654 (en relación a la escatología). 
significados que en cada momento van pudiendo ser alcanzados (31). Ahora bien -piensa Pannenberg-, este relativismo no es fácilmente conciliable con la idea diltheyana de la prioridad del todo, estaría incluso en contradicción con ella.

La "conversión a la hermenéutica", que supuso el abandono de su psicologismo primero, habría tenido que llevar a Dilthey a buscar un punto de referencia distinto de la "unidad de la vida" como referencia de la categoría de totalidad (32). Al no haber dado con él y al no poder contar ya con el "sentimiento inmediato" como base de tal referencia, surgiría la situación "contradictoria" de que, siendo prioritaria la presencia del todo, habrían de ser las partes las que, según el Dilthey tardío, ofrecen acceso a él. El relativismo habría de ser la consecuencia inevitable de tal postura. Gadamer, profesor de Pannenberg en Heidelberg, como veremos enseguida, habría sabido ir aquí más allá.

Otro punto, relacionado con el anterior, en el que también hubiera sido necesario ir más allá es el de la percepción de la historicidad de la experiencia. Una cierta actitud "contemplativa" del pasado le habría impedido a Dilthey hacerse del todo cargo de ella. ¿Cómo armonizar la "contemplación” de las objetivaciones pasadas de la acción del hombre, como fuente de la que se espera que fluya la realización de las posibilidades actuales, con la visión de la historicidad del presente como lugar siempre en movimiento y patria del sentido nuevo? ¿No queda así demasiado "oscurecida" la dimensión del futuro? De nuevo se plantearía aquí una tensión en el pensamiento diltheyano que pide una ampliación de horizontes. Dilthey se habría quedado enredado en ella por causa de su comprensión historicista del acontecer histórico como "expresión" (33) de la acción del hombre -bajo el influjo de Vico, quien sostiene que se conoce solo lo que se ha construido, ya que se poseen sus principios- y de la historia como interconexión de los efectos de dicha acción.

Es cierto que Pannenberg no ha podido encontrar en la filosofía vitalista e historicista diltheyana más que un antepasado lejano de su concepción de la "totalidad de sentido". Con todo, su recepción crítica de Dilthey es muy significativa, pues le ha permitido recoger lo positivo de la filosofía hegeliana de la historia sin caer en los excesos que Dilthey mismo había criticado ya en ella (para este filósofo, el concepto de la vida "en su totalidad" pasa a ocupar "el lugar de la razón universal de Hegel", y lo que Hegel denominaba "espíritu objetivo" es reducido a la "relación estructural de las unidades vitales, cuya continuación se encuentra en las sociedades". "Hegel construye metafísicamente; nosotros analizamos lo dado"). Es decir, que los análisis diltheyanos le han dado pistas para ver cómo, sin perjuicio de la posición central que en la hermenéutica le corresponde a la categoría de lo universal y del todo, es necesario respetar los límites impuestos a la razón humana por su historicidad.

Pasemos ahora a ver las precisiones que nuestro autor le debe al pensamiento de Gadamer en este tema de la presencia del todo en la experiencia del sentido. Entre otras cosas, el lenguaje ira adquiriendo en sus reflexiones una posición cada vez más importante, de la que carecía en las de Dilthey.

(31) Cf. Sinnerfahrung, Religion und Gottesfrage, 108.

(32) Cf. Wissenschaftstheorie, 81. 162

(33) Cf. ibíd., 78. 161. 


\subsection{El "trasfondo de sentido no dicho" : el aporte de Gadamer a la hermenéutica pannenbergiana}

La aportación fundamental de Verdad y método que resulta inspiradora para nuestro autor es la concepción de la labor hermenéutica como "fusión de horizontes". El relieve que adquiere aquí el pasado, la tradición, con su "ser diferente" respecto al hoy del intérprete y de su mundo, es un avance que ayudará a superar planteamientos psicologistas como el de Dilthey. Pannenberg valora también la consideración del lenguaje como el medio de los procesos de comprensión con el que el hombre se encuentra desde siempre. Pero, más en concreto, es la idea de que a cada palabra le acompaña un "trasfondo de sentido no dicho", la que encontrará un mayor eco en la obra pannenbergiana. Detengámonos un poco en cada uno de los aspectos mencionados.

Pannenberg se vuelve a encontrar en la hermenéutica de Gadamer con un aspecto que ya hemos descubierto como central para él: la prioridad del todo en el proceso de la comprensión. El todo sin el cual las partes resultarían incomprensibles no es otro que el todo de la historia universal. Es este el horizonte que, bien a pesar de él -según Pannenberg-, estaría pidiendo en definitiva la comprensión que Gadamer tiene de la hermenéutica de textos. La historia entraría en el proyecto del filósofo de Heidelberg de la mano de la idea de la "fusión de horizontes". Pues el nuevo horizonte en el que, en virtud del "carácter lingüístico" (34) del hombre, se funden el horizonte del objeto del pasado con el horizonte del mundo del intérprete no podría configurarse si no se dejara a lo transmitido "hablar" o "preguntar" desde su propia peculiaridad. Solo cuando se ha hecho valer la "diferencia" es posible la fusión que conlleva la comprensión.

Ahora bien, Gadamer ve en el "acontecimiento del lenguaje" la clave del proceso de comprensión, que es asimilado al modelo de la conversación: los textos "hablan" y son integrados en el nuevo horizonte de comprensión de manera similar a como el interlocutor lo es en la nueva situación creada por un diálogo logrado. La tradición "existe en el lenguaje", cuyo "auténtico producto" es la fusión de los horizontes en el proceso hermenéutico. El secreto del poder del acontecimiento del lenguaje estaría en su capacidad de mantener unido "lo dicho con la infinitud de lo no dicho" (35).

Pannenberg hace suya la observación de que todo hecho lingüístico acontece siempre en el horizonte infinito de lo no dicho. La dimensión religiosa del hombre encuentra en este rasgo del lenguaje una expresión privilegiada. Pero el hecho de que en el acontecimiento del lenguaje se dé siempre esa peculiar simultaneidad de "dicho y de no dicho, de definición y de indefinición" no justificaría la exclusión o la depreciación de su dimensión de objetividad que nuestro autor reprocha a Gadamer. Es interesante constatar la asunción crítica de las ideas gadamerianas para apreciar con claridad lo propio del planteo de Pannenberg. A partir de una intuición heideggeriana, nuestro autor señala que toda frase se halla en el entramado de rela-

(34) Cf. Hermeneutik und Universalgeschichte, en: Grundfragen systematischer Theologie, Gesammelte Aufsätze, vol. 1, 110, n. 31.

(35) Cf. ibíd., 106-113. 
ciones de una "globalidad situacional" (Bewandtnisganzheit) en la cual está anclado su significado. Pannenberg apunta que Gadamer ha ampliado esta idea convirtiéndola en la tesis de que cada frase incluye también un horizonte de sentido no dicho. Es una tesis convincente cargada de profundas consecuencias. Ahora bien, según nuestro autor no tiene por qué entrar en conflicto con el momento de la objetivización. Al contrario, una de las características propias del lenguaje es que el acto de hablar mantiene unidos lo dicho y lo no dicho, lo concreto y lo indefinido. De ahí que el horizonte de sentido no dicho de lo hablado no tenga por qué estar definido de antemano en la globalidad situacional de un mundo originariamente dado-ahí (zuhanden). Más bien habrá que suponer, subraya Pannenberg, que el entramado de relaciones de cada frase y de cada experiencia de significado se adentran en lo indefinido de una totalidad de sentido que solo adquiere contornos y textura más precisos en el más estrecho círculo de lo vivenciado (Erlebtes) y de lo hablado (36). Porque el lenguaje tendría, eminentemente, la función de representar la realidad, las cosas; una función presente de una u otra manera en todo lenguaje, también en el del coloquio, aunque su expresión más pura sea la de las proposiciones o declaraciones. Ahora bien, esto no quiere decir que el uso de proposiciones "objetivizantes" tenga que ignorar el horizonte de lo no verbalizado en ellas; por el contrario, ellas mismas invitan a poner al descubierto sus múltiples implicaciones, median entre lo que dicen y lo no dicho (37).

El lenguaje sería, pues, ciertamente, el lugar en el que acontece la comprensión del sentido, pero no su marco último de referencia. El mismo remite a lo que representa y a sus diversos contextos, es decir, a una historia que, en definitiva, habría de ser historia universal. Solo un proyecto de historia universal podría ofrecer el marco adecuado para concebir coherentemente la "fusión de horizontes" que implica, por cierto, la configuración de un nuevo lenguaje para el horizonte nuevo. Nuevamente la distancia entre maestro y discípulo es lo que permite que salga a la luz lo propio del segundo, pues este encuentra que es solo la minusvalorización de la estructura propositiva del lenguaje la que puede hacerle ignorar a Gadamer que la comprensión del contenido de un texto exige el bosquejo de una historia de dicho contenido, ya que, fuera del horizonte de dicho bosquejo, no se pueden relacionar adecuadamente una con otra la perspectiva del contenido propio del texto, condicionada por su localización histórica, y la actual perspectiva del contenido propia del intérprete. Y puesto que las diversas áreas temáticas están, a su vez, conectadas unas con otras, la tarea hermenéutica no solo exige bosquejos de la historia de esta o de aquella área temática, sino bosquejos de historia universal que abarquen las cambiantes interconexiones de todas las diversas áreas temáticas (38).

(36) Cf. Wissenschaftstheorie, 179ss.

(37) Cf. Hermeneutik und Universalgeschichte, 114.

(38) Cf. ibíd., 118. 


\subsection{El aporte de Habermas: la anticipación en la historia de la "vida lograda", un criterio seguro para enjuiciar críticamente el presente}

Pannenberg ve en la crítica que Habermas hace de la "ontologización del lenguaje" (39) por Gadamer, de su subjetivismo y del excesivo papel (autoritario) que concede a la tradición una confirmación de su propia crítica y de sus propios postulados.

La necesidad de un punto de referencia para la interpretación crítica del presente le ha hecho también al filósofo de Frankfurt encarar la necesidad de un proyecto de historia universal. El consenso logrado en el solo medio del lenguaje, vehículo creador de la tradición, no estaría nunca libre de la sospecha de su posible radical deformación. Solo la anticipación de la "vida lograda", del fin hacia el que se encamina la humanidad en su proceso de autorrealización, sería capaz de ofrecer un criterio seguro para enjuiciar críticamente el presente. Habermas se orientaría, pues, con este método "dialéctico" a "la totalidad en cuando tal", que el método "hermenéutico" se creería dispensado de tematizar (40).

En otro orden de cosas, nuestro autor está con Gadamer, pues no puede aceptar la convicción habermasiana de la prioridad de la acción frente a la experiencia de sentido. Habermas habría ido demasiado allá al buscar en la "interpenetración de lenguaje y praxis" (41) un lugar desde el que poner coto a la carga de autoritarismo e irracionalidad que va unida a la prepotencia de la tradición en la teoría hermenéutica gadameriana. Pannenberg no tiene ciertamente nada contra esta intención ni en contra de que se coloque al lenguaje en el contexto de "lo no verbal" (42). El lenguaje mismo apunta a más de lo que Gadamer veía en él. Pero eso no justificaría la radical subsunción de toda la temática "lingüística" en el horizonte presuntamente más abarcador de la praxis, de la acción (comunicativa), que Habermas se cree obligado a realizar con el fin de evitar las mencionadas máculas.

No sería acertado descalificar como "circular" la argumentación sobre la comprensión del sentido que se desprende de una observación de "la experiencia del sentido en su lógica intralingüística". Para evitar el "círculo" nuestro autor cree que distinguiendo entre "precomprensión" (Vorverständnis) y "preconcepto" (o prejuicio [Vorbegriff]) se puede encontrar un camino más adecuado y fructífero que el de recurrir al concepto de acción como totalidad del proceso de interacción social (43). Se puede y debe salvar la observación de Gadamer de que la experiencia del sentido es relativamente independiente del hecho de que sea perseguida expresa y voluntariamente, pues acontece también dónde y cuándo no se la busca, de igual modo que precede a la acción, cuya constitución implicaría más bien desde el principio un sentido ya experimentado.

Pannenberg trata, pues, de definir su lugar hermenéutico entre Gadamer y Habermas. La lógica de la experiencia del sentido descubierta en Dilthey, constituye la base de su concepto básico de totalidad de sentido (Sinntotalität) (44). El hori-

(39) Wissenschaftstheorie, 188.

(40) Cf. ibíd., 186 ss.

(41) Citado en ibíd., 200.

(42) Ibíd., 202.

(43) Cf. ibíd., $201 \mathrm{s.}$

(44) Cf. M. Dumas, Expérience religieuse et foi chrétiene, 316. 
zonte del todo acompaña inevitablemente a cada experiencia particular. Ante el problema de precisar el carácter del todo más abarcante de los procesos de comprensión del sentido, Pannenberg no se contenta ni con el "acontecer del lenguaje" ni con el "proceso de la acción comunicativa", sino que tras el primer concepto ve apuntar el horizonte de una historia universal que es exigido ya explícita, aunque reductivamente, por el segundo.

\section{5. La realidad tiene una estructura de sentido previo a la actividad lingüística: el} aporte de Popper a la descripción de las características "mágicas" y "míticas" del lenguaje

Hay todavía una función y una virtualidad del lenguaje que, como ya hemos apuntado, es dejada en la sombra por los pensadores a los que nos hemos referido hasta aquí: la de representar, con mayor o menor acierto, la realidad prelingüística (45). Esta laguna tendría consecuencias serias a la hora de hacerse una idea de lo que es la percepción del sentido, pues llevará a reducirlo a una mera actividad creadora del hombre. Pannenberg califica de intencional la concepción de sentido a que da lugar esta postura.

Sin embargo hay una serie de pensadores, cuales son los representantes del positivismo lógico, del racionalismo crítico y de la filosofía del lenguaje, que se centran ante todo en la mencionada función que nuestro autor echa de menos en los análisis de los hermeneutas reseñados más arriba. Su concepción del sentido sería referencial, pues lo definen en primer lugar por las referencias de unas palabras a otras en la frase y de la frase a otras frases en el discurso y también por la referencia de toda la construcción lingüística al objeto significado (46).

Pannenberg está de acuerdo con el positivismo lógico en que toda proposición, cuya verdad o falsedad no pudiera por principio ser comprobada de ninguna manera, carecería de sentido (47). Pues la adecuación a lo dicho es pretensión del lenguaje mismo. De ahí que toda proposición tenga una estructura al menos implícitamente hipotética: su verdad queda pendiente de la comprobación de su adecuación a lo que en ella se expresa, al objeto afirmado (48).

Esto es así en virtud de la capacidad propia del lenguaje de captar verbalmente las cosas diferenciándolas al mismo tiempo de la forma lingüística en la que son representadas. Por eso es posible el entendimiento entre distintos hablantes y de ahí, también, el fenómeno de la pluridimensionalidad de las manifestaciones lingüísticas. Los hablantes se entienden sobre algo, pero también ocurre que lo dicho o no resulta ser lo que se quiere significar o significa más de lo que en realidad se pretendía. Aquí subyace, a juicio de Pannenberg, una intuición básica que ya había sido descrita por Heidegger, en cuanto el lenguaje da nombre a la esencia de los fenómenos anticipando su futuro, con lo que el lenguaje expresa sin duda más de lo que está ahí (vorhanden) en las cosas.

(45) Cf. I. Orellana, La cuestión del estatuto científico de la teología: Popper-Pannenberg, Salamanticensis 45 (1999), 443-474.

(46) Cf. Wissenschaftstheorie, 206s.

(47) Cf. ibíd., 373

(48) Cf. Sinnerfahrung, Religion und Gottesfrage, 102-103 
Todas estas características del lenguaje han sido puestas de relieve en los análisis de lo dicho, de las proposiciones, a los que se han dedicado los esfuerzos de las corrientes filosóficas que acabamos de mencionar, desde Wittgenstein hasta Popper. Pannenberg encuentra en ellas un apoyo para su tesis de que la realidad tiene una estructura de sentido previo a la actividad lingüística. Es un sentido que ha de ser hallado, que no es en modo alguno dado o creado por el hablante. El lenguaje es el medio y, al mismo tiempo, la invitación a la búsqueda.

Este es un aspecto que Pannenberg valora mucho, pues ofrece el derecho de suponer estructuras de sentido más allá del círculo de las construcciones linguiísticas, lo que ha sido recibido de la función representadora del lenguaje, en particular de las afirmaciones; así, el sentido es accesible a través del lenguaje, pero no es un producto de este, pues si así fuera, no tendría sentido ninguna forma de hablar en frases afirmativas; pero sí tiene sentido el uso de estas frases, entonces es necesario suponer una estructuración de lo real ya de alguna manera con sentido antes de su aprehensión lingüística, aunque no se articule esa estructura de sentido más que por medio del lenguaje (49).

Ahora bien, Pannenberg critica al positivismo lógico una nueva comprensión reductiva del lenguaje. Las proposiciones son ciertamente una manifestación primordial del lenguaje, pero el concepto de sentido no se reduce a un lenguaje meramente reproductor del mundo. La crítica de Popper a la teoría de las proposiciones-protocolo, en las que el positivismo lógico veía la expresión más perfecta de la capacidad representativa del lenguaje, iba ya en la misma dirección que la de Pannenberg. La idea de un lenguaje-tipo que se redujera a la reproducción inequívoca de la realidad, es decir, el lenguaje neutro "de pura observación", no pasa de ser una ilusión. Pero tampoco Popper se habría liberado del todo de esa ilusión. Su insistencia en el rechazo de la cientificidad de la pregunta filosófica (metafísica) por el ser y la verdad última de las cosas delataría una insuficiente percepción de la problemática que se encerraría en su propia concepción de las frases-base. Estas -observa Pannenberg- están también inmersas en el lenguaje ordinario, sin el cual no son formulables. Popper mismo lo habría visto así al reconocer el factor de "convención" que conlleva su formulación. Si esto es así -concluye Pannenbergya aquí, es decir, en el lenguaje "científico" de Popper, se plantearían implícitamente problemas filosóficos y religiosos. Porque ya en las frases-base están implicadas las más complejas interconexiones de sentido.

Nos gustaría en fin referirnos a un último aspecto de la influencia de Popper en Pannenberg, al cual solo hemos aludido, pero que a nuestro juicio está asumido en la estructura de pensamiento de este último, y al cual, a nuestro juicio, no siempre se le presta toda la atención que requiere.

Si el positivismo lógico insistía en la verificación empírica como criterio de sentido, será el racionalismo crítico de Popper el que pondrá en cuestión tanto el criterio mismo de verificación como la relación o identificación de esta con el sentido (en lo que sigue hacemos referencia a su obra fundamental Lógica de las investigaciones científicas de fuerte influencia en Pannenberg, sobre todo en su Teoría de la ciencia y teología).

(49) Cf. ibíd., 103-107. 
Respecto de esto último (es decir, la mencionada identificación entre "sentido" y "verificación" empírica) dirá, en efecto, Popper en relación con el "deseo" del positivismo lógico de ver meros "problemas aparentes" en los problemas filosóficos: "Este deseo [...] es naturalmente siempre realizable; nada es más fácil que poner de manifiesto una cuestión como 'problema aparente y carente de sentido'. Solo hace falta utilizar el concepto de 'sentido' de manera suficientemente estrecha para poder declarar acerca de todas las incómodas cuestiones que no se puede hallar en ellas 'sentido' alguno; y al decir que únicamente tienen 'sentido' las cuestiones de las ciencias empíricas, viene a carecer de sentido cualquier debate sobre el concepto de sentido: una vez entronizado este dogma del sentido, queda exento para siempre de cualquier ataque" (50).

Es decir, el positivismo lógico, según Popper, se ha fabricado a su propia medida y según sus propias conveniencias teóricas un criterio de "sentido", y ello no es legítimo. Lo adecuado sería desconectar la problemática del sentido de la cuestión del criterio que se juzgue apropiado para definir lo que se considera una proposición "científica". Pero en esto Popper también se va a separar del positivismo lógico al proponer su propio criterio, el de "falsabilidad", frente al criterio positivista de "verificabilidad". Tal criterio de "falsabilidad" deberá ser el verdadero criterio de "demarcación" (Abgrenzung) entre lo "científico" y lo que no es científico, dado que el criterio de "verificabilidad" es incapaz de justificar los propios sistemas o teorías, que según Popper "nunca son empíricamente verificables". De aquí que para que enunciados que no son verificables puedan, sin embargo, ser tenidos como "empíricos" (y, por lo tanto, "científicos") será necesario recurrir a un criterio distinto del de "verificabilidad". Tal criterio es justamente el de "falsabilidad": "No exigimos que el sistema pueda ser justificado por la vía empírico-metódica de manera definitiva y positiva, pero exigimos que la forma lógica del sistema posibilite el que ello ocurra por la vía de la comprobación metódica de manera negativa: Un sistema empírico-científico debe poder fracasar en la experiencia" (51).

Popper ha insistido frente a los representantes del positivismo lógico en que su propio criterio de falsabilidad no es un criterio de "sentido" a la manera como lo es el criterio de verificabilidad de los positivistas, dado que lo que a él le interesa no es el "problema del sentido", sino el "problema de la demarcación" entre lo "científico" y lo "metafísico". Y así quiere exactamente Popper ser entendido al establecer frente al criterio de verificabilidad positivista su criterio de falsabilidad, que -dice"serviría para la demarcación de los sistemas de enunciados científicos frente a sistemas, absolutamente dotados de sentido, de enunciados metafísicos". Su criterio, pues, de "falsabilidad" no está ahí en modo alguno para decidir qué tipo de enunciados tienen o no "sentido", tal como ocurre en el Wittgenstein del Tractatus o en los positivistas lógicos que se apoyan en esta misma obra. Según Popper, la radical "superación" de la metafísica de que hacen gala los positivistas al declarar a esta sin sentido, una vez establecida la identificación entre "sentido" y "verificabilidad", se vuelve en realidad también en contra de ellos. En efecto, "este radicalismo -objeta Popper- destruye junto con la metafísica también la ciencia: tampoco las leyes de la

(50) Logik der Forschung, Tübingen ${ }^{3} 1969,23-24$.

(51) Ibíd., 14-15. 
naturaleza son lógicamente deducibles de enunciados experimentales [...]; no serían [estas leyes], por tanto, en el caso de que se aplicara de manera consecuente el criterio wittgensteiniano de sentido, sino "enunciados aparentes, sin sentido", "metafísica". Con lo que tal criterio de demarcación fracasa" (52). En cambio, la tesis de Popper sostiene que el criterio de falsabilidad "permite una demarcación suficientemente precisa de las "ciencias de la realidad", de los sistemas empírico-científicos, frente a los sistemas metafísicos (y también contra los convencionalistas-tautológicos), sin tener que calificar como "sin sentido" a la metafísica". Nosotros creemos que cualquier acercamiento al planteo hermenéutico de Pannenberg deberá tomar en cuenta la posibilidad que le ofrece Popper de poder volver a mediar entre ciencia y metafísica (y, por extensión argumental, teología), a pesar de todas las modificaciones y críticas que se producen en la asunción del pensador de las ciencias en nuestro autor.

Damos aquí por concluida esta esquemática evocación de lo que hemos llamado la conformación de la idea central pannenbergiana de la "totalidad de sentido". Sobre la idea en cuanto tal, volveremos en seguida (3). Pero, a modo de conclusión, hagamos una pequeña referencia a los análisis que en torno al lenguaje ha realizado nuestro autor en su obra Antropología en perspectiva teológica (53). Como hilo conductor de los mismos hemos creído ver el intento de mantener una posición media entre las dos grandes tradiciones a las que nos venimos refiriendo: la tradición hermenéutica, que hace hincapié en la presencia del todo en la experiencia del sentido, y la tradición analítica, que parte de proposiciones singulares cuyo sentido -o adecuación a lo representado- iría ligado a su comprobación experiencial.

Pannenberg estudia a fondo el fenómeno del lenguaje en el marco de su análisis de las bases del "mundo común" de la cultura. Le dedica un amplio espacio porque en la "institución original” (Urinstitution), que es el lenguaje, se reflejaría de manera paradigmática la importancia de la conciencia de sentido para la configuración de las instituciones sociales. Dicha conciencia es un dato previo (Vorgegebenheit) a los individuos cuyas raíces se encontrarían en el campo de lo mítico y de la fe. El origen religioso del lenguaje se refleja en su permanente tensión entre la posibilidad de disponer de las cosas por medio de los nombres -dimensión mágicay la presencia activa en él de la oculta realidad originaria del mundo -dimensión mítica-. Es la tensión lingüística entre representación y expresión. No se podría eliminar o minusvalorar ninguno de los dos aspectos sin desfigurar o malentender la fundamental realidad antropológica del lenguaje.

Por un lado, pues, habría que ir más allá de las teorías performativas o del acto lingüístico que pretenden reducir el sentido a la acción de la expresión. Pues el fenómeno que toman como caso paradigmático, el de la conversación, rompería ya con esos moldes interpretativos. En ella se da siempre también una referencia temática u objetiva. Pero también es cierto que lo típico de esta manifestación lingüística es lo que Pannenberg llama "la vida de la conversación"-o su "espíritu"-, en la que

(52) Ibíd., 255.

(53) Cf. Anthropologie in theologischer Perspektive, 83.192.278.347ss.381ss.376.395; ver además una síntesis en, Il linguaggio teologico tra la prospettiva di totalità ontologica e la frammentarietà del sapere, Protestantesimo 54 (1999), 357-366. 
los dialogantes son como enrolados y a la que se tienen que abandonar para que la comunicación resulte realmente lograda. Aquí se muestra de manera peculiar cómo el lenguaje saca al hombre fuera de sí al remitirle a una realidad anterior a su acto lingüístico que se hace presente en la palabra. El hablante no es totalmente "dueño" de sí al hablar. Es el rasgo "mítico" del lenguaje.

Por otro lado, el hecho de que el lenguaje no pueda ser reducido a una actividad creadora de sentido, no ha de hacer desplazarse el péndulo al otro extremo llevando a ver solamente en él un perfecto mecanismo reproductor de una objetividad plenamente dada. Sería reducirlo a su dimensión "mágica".

El proceso de comprensión del sentido se da en medio de esta tensión permanente del lenguaje, siempre entre infinitud y particularidad. Un proceso en el que está implicada la que Pannenberg llama "totalidad de sentido".

\section{LA HERMENÉUTICA COMO MEDIACIÓN ENTRE EL CONCEPTO FILOSÓFICO DE “TOTALIDAD DE SENTIDO” Y LA IDEA DE DIOS PRODUCTO DE LA REVELACIÓN}

\subsection{La totalidad de sentido como anticipación. Reinterpretación de la metafísica a través de la hermenéutica contemporánea: base interpretativa y crítica necesaria para la teología (54)}

Aquí no podemos detenernos en los motivos (sobre todo la insistencia en la idea de lo contingente) (55) que mueven a Pannenberg a juzgar inaceptable el "compromiso" de la teología tradicional con la metafísica clásica (en analogía a la crítica heideggeriana a la ontoteología). En el fondo, era que esta, pretendiendo dar una imagen exhaustiva de la divinidad, no podría permitir desde sus propios presupuestos una valoración realmente positiva de la revelación de un Dios personal (56). Solo a modo de ejemplo es interesante constatar cómo nuestro autor trae a este propósito a colación los testimonios de Ireneo y Clemente, ya que estos habrían considerado la incomprehensibilidad de Dios postulada por la filosofía como un "lugar vacío que podría ser rellenado con cualquier tipo de contenidos de revelación" (57). Y a continuación agrega: "La revelación no fue comprendida como revelación del Dios incomprensible sino como ampliación positiva de su incomprehensibilidad [...] Ireneo podría haber encontrado lo nuevo de la revelación de Dios en Cristo justo en la abierta incomprehensibilidad de Dios en su revelación. Al no haber llevado a cabo esta usurpación del concepto filosófico de Dios y al haber

(54) Cf. Ch. Mostert, God and the Future. Wolfhart Pannenberg's eschatological Doctrine of God, London-Nueva York 2002, sobre todo 55-88.

(55) Cf. Die Kontingenz der geschöpflichen Wirklichkeit, en: Beiträge zur Systematischen Theologie. Natur und Mensch-und die Zukunft der Schöpfung, vol. 2, Göttingen 2000, 69-81.

(56) Cf. Metaphysik und Gottesgedanke, Göttingen 1988, 7-19 (Metafísica e idea de Dios, Madrid 1999).

(57) Die Aufnahme des philosophischen Gottesbegriffs als dogmatisches Problem der frühchristlichen Theologie, en: Grundfragen systematischer Theologie, Gesammelte Aufsätze, vol. 1, 324 (La asimilación del concepto filosófico de Dios como problema dogmático de la antigua teología cristiana, en: Cuestiones fundamentales, 93-150). 
colocado, en lugar de eso, al contenido de la revelación del amor de Dios como una segunda cosa al lado de la incomprensible grandeza de Dios, inició un fatal camino: el de un compromiso que propiamente era imposible, tanto desde la filosofía como desde la teología; el camino de la superposición en el concepto de Dios de elementos filosóficos y elementos específicamente teológico-revelados, el camino, por tanto, cuya configuración clásica habría de ser mucho después la obra de la escolástica latina" (58). En otro lugar Pannenberg agrega que "el planteamiento de la cuestión de Dios como origen de la realidad en su totalidad no condujo, en consecuencia de su propia temática, a la historicidad de la automanifestación de Dios. Por eso, la tradición cristiana tuvo que aparecer allí necesariamente como algo 'sobrenatural' al lado de la teología filosófica 'natural'. Y entonces la historicidad de la automanifestación de Dios quedó como algo que se le añadía solo externamente a la precisa definición de Dios como origen del cosmos" (59). Estas dos breves alusiones nos muestran la convicción de nuestro autor que, en realidad, cualquier metafísica presentaría un concepto "deficitario" de Dios por cuanto no tendría acceso al carácter personal de la divinidad: "El nombre 'Dios'... solo le corresponde al concepto de absoluto en virtud de su relación con la religión... De ahí que no podamos valorar lo absoluto de la metafísica más que como un acercamiento a las imágenes de Dios de las religiones, eso sí, como un acercamiento desde el punto de vista de la generalidad racional... el modo propio del ser de Dios no le es accesible a la reflexión metafísica más que, en todo caso, de una forma muy general y, por tanto, muy limitada, y puesto que, además, la idea metafísica de lo absoluto, sin una teoría definitiva de la realidad del mundo que le corresponde, puede aparecer como una necesidad de la reflexión humana meramente subjetiva, tampoco puede la metafísica emitir un juicio definitivo sobre la existencia de Dios. En último término tiene que dejar este juicio a la pugna de las religiones sobre la verdad de sus concepciones de Dios, aunque le corresponda a ella una función regulativa en la contienda" (60). Pero ya desde bien pronto habla también nuestro autor de que la teología, por exigencias de la idea misma de Dios, habrá de ser "coadministradora de la herencia de la metafísica" (61). Su convicción de que el tiempo de "la inocencia metafísica" está ya pasado, no le impide rechazar abiertamente la postura, "hoy tan querida", de quienes creen tener que darle la "despedida" a la "espinosa problemática" planteada por el pensamiento metafísico (62). "El ejemplo más significativo" de que "aquella presuntamente tan reprobable metafísica, en cuya superación se ha estado trabajando" no está en realidad tan superada seguiría siendo, a pesar de todo, Hegel. Lo que más bien estaría haciendo falta "es que se recobre el significado de la metafísica para la filosofía" (63). A la teología le va mucho en ello; el haber tratado de expurgarla "de todo elemento metafísico" ha sido un empeño que la ha beneficia-

(58) Ibíd., 325.

(59) Wissenschaftstheorie, 313.

(60) Systematische Theologie, vol. 1, Göttingen 1988, 193 (Teología Sistemática, vol. 1, Madrid 1992).

(61) Die Aufnahme des philosophischen Gottesbegriffs, 343; cf. Ein theologischer Rückblick auf die Metaphysik, en: Beiträge zur Systematischen Theologie, vol. 1, 27-31.

(62) Cf. Gottesgedanke und menschliche Freiheit, Göttingen 1972, 41. 62

(63) Pannenberg enjuicia su propia teología (entrevista), 277. 
do bien poco (64). Pero es que, además, el tema de la filosofía misma en su gran tradición, la metafísica, es decir, el tema de la unidad y totalidad de lo real, sería inevitable para el pensamiento en cuanto tal.

Para subrayar aún más la idea del último párrafo, es interesante recoger el diálogo de Pannenberg con D. Heinrich (65). Nuestro autor considera, al igual que este filósofo, que sin metafísica no es posible "vida plena" (gelungenes Leben) o una orientación reflexiva y comprehensiva sobre la vida consciente. No es posible ocuparse de temas como el sentido y la verdad sin contemplar la herencia metafísica de la que procedemos (66). Sabe Pannenberg que venimos de muy lejos y ha dedicado elogios al concepto de tradición como también a la tradición metafísica occidental. Nuestro autor llega incluso a preguntarse si no habría de sostener que la principal tarea de la teología consiste en cuidar y administrar con pasión las tradiciones metafísicas de la humanidad, a las que la filosofía parece haber renunciado.

La unidad y totalidad de lo real ya no podría ser pensada con las categorías cosmológicas de la metafísica clásica, pero que tiene que seguir siendo pensada es algo que Pannenberg ha considerado siempre como ineludible; en el marco de sus estudios de hermenéutica y teoría de la ciencia ha llegado a formular cómo cree él que se ha de llevar a cabo esa tarea. Unidad y totalidad pueden y deben ser pensadas hoy como "totalidad de sentido", un concepto de "dimensiones "metafísicas" (67). En el punto anterior (2) hemos pasado ya revista a su conformación; detengámonos ahora a enumerar siquiera los rasgos básicos de esta idea central de la, por así llamarla, nueva metafísica, cuya rehabilitación le interesa tanto a nuestro autor.

La idea de la unidad y de la totalidad, no es "solo una invención de los filósofos" (68). La filosofía y la teología se topan necesariamente con ella. Ahora bien, una cosa es que sea inevitable plantearse la cuestión de la totalidad y otra muy distinta, un pensamiento totalitario tributario del "mito de una razón total" (69). La "metafísica" pannenbergiana no tendría nada que ver con un pensamiento de este último tipo. Pues la "totalidad de sentido" (70) estaría de tal modo más o menos difusamente dada con y en cada experiencia particular (3.1.1), que no se la podría pensar ni como construida (3.1.2) ni como presentísticamente conclusa (3.1.3), sino conllevando siempre un elemento de anticipación que impondría a toda experiencia, y a todo tipo de articulación lingüística o conceptual de la misma, un cierto carácter hipotético (3.1.4).

3.1.1. En efecto, nuestro autor, siguiendo, como ya hemos visto, a Dilthey, insiste en que en nuestra experiencia vital, lo particular no es aprehendido más que como "recortado" o destacado del horizonte infinito del todo en el que siempre nos

(64) Cf. Gottesgedanke und menschliche Freiheit, 29.

(65) Cf. Metaphysik und Gottesgedanke, 7ss.

(66) Cf. A. Bertuletti, L'unicità piuttosto che l'infinita differenza: riflessioni a margine di un saggio recente su Pannenberg, Teologia 28 (2003), 416-424.

(67) Wissenschaftstheorie, 116; cf. Systematische Theologie, vol. 3, 636.

(68) Cf. Die Bedeutung der Kategorien "Teil" und "Ganzes" für die Wissenschaftstheorie der Theologie, en: Beiträge zur Systematischen Theologie, vol. 1, 86.

(69) Wissenschaftstheorie, 193.

(70) Cf. ibíd., 204. 312. 
movemos. De modo que, en contra de una primera impresión superficial, no se podría decir que "lo particular fuera a ser de por sí más fácilmente accesible que el todo" (71). Claro que, por su parte, el todo tampoco es accesible más que en y a través de lo particular. Es esta la que Pannenberg llama la "lógica de la experiencia del sentido" (72), según la cual lo particular y lo total se encuentran en una relación de reciprocidad tan estrecha que habría que hablar -siguiendo a Troeltsch- de un "grado más alto de generalidad", en el que "lo particular y lo general coinciden en el sentido de que toda particularidad necesita las mismas determinaciones generales para su explicación" (73).

Estas tesis pannenbergianas se basan ante todo en lo que podríamos llamar la experiencia lingüística o, más precisamente, en una observación de "la estructura de las aserciones" y de su "pretensión de verdad" (74).

3.1.2. En nuestra experiencia vital, en nuestra certeza ("Gewißheit") (75) y en nuestra conciencia moral ("Gewissen") (76), acontece, pues, una "percepción originaria del todo" (77) en relación a la cual adquiere precisión cada interpretación particular del sentido de un determinado hecho o cosa. De aquí que no se puede hablar propiamente de "dar" sentido como si este fuera una creación del que lo percibe. Al contrario, el sentido viene constituido por la totalidad, que no solo precede al acto de percepción, sino que posibilita también la configuración de la identidad del sujeto perceptor. En este sentido, la experiencia, en la que siempre está "latente" una totalidad de sentido, tendría prioridad sobre cualquier tipo de acción (78). Por eso son inadecuadas, para nuestro autor, las teorías "intencionales" que pretenden explicar el fenómeno de la percepción del sentido como fruto de una $\mathrm{u}$ otra actividad creadora del mismo proveniente del perceptor.

3.1.3. Ahora bien, a diferencia de lo que habría ocurrido en la metafísica tradicional, el todo de sentido no es simplemente la totalidad del ser, de lo que está sin más ahí a la mano (vorhanden), considerado como un sistema cerrado (resulta interesante aquí aludir a una idea similar en Heidegger, pues el todo se traduce para él en la preocupación metódica y sistemática por el desvelamiento de la verdad del ser y del hombre que vive extático a la vera del mismo. La cautela filosófica de Heidegger, especialmente ante lo divino o el Dios, está determinada por su conciencia de que la verdad adviene al hombre como un don ajeno al mismo, y, por ello, como algo que el hombre no puede en definitiva cosificar o manipular). Pannenberg insiste, por el contrario, con Adorno, en que "el sistema de lo simplemente presente"

(71) Cf. Stellungnahme zur Diskussion, en: J. Robinson-J.B. Coob (eds.), Die Offenbarung Gottes in Jesus von Nazareth, Zürich-Stuttgart 1967, 309.

(72) Wissenschaftstheorie, 193.200.

(73) Ibíd, $116 \mathrm{~s}$.

(74) Cf. Die Bedeutung der Kategorien "Teil" und "Ganzes", 85ss.

(75) Wahrheit, Gewißheit und Glaube, en: Grundfragen systematischer Theologie. Gesammelte Aufsätze, vol. 2, Göttingen 1980, 261.

(76) Anthropologie in theologischer Perspektive, 299 s.

(77) Cf. Wahrheit, Gewißheit und Glaube, 261.

(78) Cf. Wissenschaftstheorie, $100 \mathrm{ss}$. 
es el "todo falso", no verdadero (79). Y aquí sí que se abre un amplio campo a la actividad interpretativa; este es el lugar de los diversos proyectos que, sobre el trasfondo de la percepción originaria del todo dado, compiten entre sí en la comprensión de la realidad. Son interpretaciones que permanecen siempre problemáticas y discutibles (strittig) (80). No podía ser de otra manera dada la apertura de la totalidad, que condiciona la relativa "vaguedad" o indeterminación de su percepción y formulación, la susceptibilidad constante de mayor precisión que caracteriza a estas y, en definitiva, la incapacidad de la conciencia finita de acceder a ella de manera acabada (81).

3.1.4. Con todo, la "totalidad de sentido" es algo más que una "pura idea regulativa de la unidad del contenido de la experiencia", pues no puede ser considerada como un principio de integración secundario o añadido a la multiplicidad de la experiencia, sino que es ya de por sí un elemento constitutivo de la misma (82). ¿Cómo? Solo como mera anticipación. He aquí el punto clave de la hermenéutica pannenbergiana en el que radica su capacidad de diálogo crítico con Hegel, Dilthey, Habermas o Popper (83).

Con Hegel puede Pannenberg mantener la necesidad de la idea del todo y de la historia universal evitando las "aporías del idealismo" (84). Ni el todo ni la historia están nunca "comprehendidos" del todo, sino tan solo "precomprendidos", gracias a la "aparición anticipada de lo definitivo" en medio de lo provisional (85).

Es la anticipación la que, frente a Dilthey, permite leer ya ahora el significado de cada experiencia a la luz del futuro último. En diálogo con Habermas el concepto de anticipación le sirve a nuestro autor para defender su tesis de la prioridad del todo (dado en la experiencia) sobre la acción, rechazando así las imputaciones de "circularidad" o de "ideología". La proposición habermasiana de la acción comunicativa libre de imposiciones como instancia última de la búsqueda del sentido que desenmascararía como ideológica la presuposición de cualquier otra instancia preordenada, es, para nuestro autor, ella misma ideológica por cuanto que necesariamente ha de ocultar que de hecho la experiencia implica una anticipación del todo. Dicha anticipación no es, como queda ya dicho, en un primer momento más que una vaga e indefinida presencia del todo en la experiencia, en la familiaridad del individuo con su medio vital social, que le posibilita una "precomprensión" atemática del mismo. Explícito solo se hace el todo después en los diversos "preconceptos" o "proyectos" que lo adelantan de forma hipotética sobre la base de aquella precomprensión. El

(79) Wie wahr ist das Reden von Gott? Die wissenschaftstheoretische Problematik theologischer Aussagen, en: S. M. Daecke et al (ed.), Grundlagen der Theologie-ein Diskurs, Stuttgart 1974, 74.

(80) Cf. Wissenschaftstheorie, 100.104.217.

(81) Cf. ibíd., 115s.155.179 n. 360.195.217; Anthropologie in theologischer Perspektive, 396. 499; Gottesgedanke und menschliche Freiheit, 66.

(82) Cf. ibíd., 65.

(83) Cf. L. Kugelmann, Antizipation. Eine begriffsgeschichtliche Untersuchung, Göttingen 1986, sobre todo, 52-59. 231 ss.

(84) Cf. Heilsgeschehen und Geschichte, 41ss.

(85) "El todo [...] no acabadamente en el concepto (Begriff), sino solo en la anticipación (Vorgriff)" (Über historische und theologische Hermeneutik, en: Grundfragen systematischer Theologie, Gesammelte Aufsätze, vol. 1, 150). 
elemento hipotético aquí implícito pide de por sí la acreditación de cada proyecto en cuestión, con lo cual no se da lugar a la circularidad lógica.

En cuanto a Popper, Pannenberg se apoya también en la idea de la anticipación -que juega para el mismo Popper un importante papel- para mostrarle que la cuestión de la verdad no puede separarse de la cuestión "metafísica" de la esencia de las cosas, pues los juicios hipotéticos, anticipatorios, están haciendo referencia al problema clásico de esencia y apariencia.

\subsection{La búsqueda de una superación del ghetto histórico-salvífico de la teología cristiana: hacia un "correlato" de la idea de Dios (86)}

El desmoronamiento de la metafísica clásica arrastró consigo la crisis de la idea de Dios. No se podía esperar otra cosa si se tiene en cuenta que esta conlleva una referencia al todo de la realidad y a su unidad (recordemos de modo ejemplar la parábola del loco de La gaya ciencia), sin la cual el vocablo "Dios" no sería más que una palabra vacía y, a la postre, superflua. Pero, como venimos viendo, Pannenberg cree que con la metafísica clásica no ha desaparecido toda posibilidad de pensar el todo de la realidad, es más, que sigue siendo necesario pensarlo como totalidad de sentido. Esta sería una gran "huella" de Dios "en las cosas del mundo" que permitiría e incluso exigiría a la filosofía, es decir, al pensamiento que se pregunta por la realidad en general y en cuanto tal, al menos plantearse la cuestión de Dios, mostrarse permeable a ella, aunque sea haciendo frente a una moda que tiene por progreso la prohibición que de dicha cuestión se imponen a sí mismos ciertos tipos actuales de pensamiento.

En efecto, desde la idea de totalidad a la idea de Dios sería posible un "camino de vuelta" (Rückgang) (87) que Pannenberg ha ido recorriendo en diversas etapas, yendo cada vez más hacia el fondo de la cuestión. El punto de partida fue el problema de la totalidad de la historia.

El historiador que haya roto con la concepción positivista de la historia y trate de explicarse la simultaneidad de regularidad e individualidad contingente que caracteriza la unidad y continuidad de los procesos históricos, se verá de manera imperceptible ante "el problema" de Dios: ¿o puede fundarse dicha unidad de otra manera que no sea en referencia a una instancia "trascendente"? (88). La instancia de la que Pannenberg hablaba ya en 1959, la idea de Dios que habría de resultarle "imprescindible" (89) al historiador, era explícitamente la del Dios bíblico. Porque no es desde "una lógica del Absoluto previa" (90) a la historia misma desde donde se puede apreciar la contextura precisa de la unidad de esta, sino solo desde un acercamiento detenido a sus vicisitudes y, muy en concreto, al ámbito de ella en el que la cuestión de Dios resulta ya imposible de desoír: la historia de las religiones. Volveremos en seguida sobre el tema. Aquí nos interesa subrayar que para Pannen-

(86) Cf. Ch. Mostert, God, 89-126; F. Lienhard, W. Pannenberg: Une théologie de l'historie et de la résurrection, Irenikon 70 (1997), 342ss.

(87) Cf. Die Bedeutung der Kategorien "Teil” und "Ganzes", 94.

(88) Cf. Gottesgedanke und menschliche Freiheit, 73ss.

(89) Cf. Heilsgeschehen und Geschichte, 75.

(90) Cf. ibíd., 76. 
berg la cuestión de Dios no se responde desde la mera problemática del "todo de la historia", pero esta sí que "se corresponde" (entspricht) (91) con el carácter de universalidad que aquella implica. He aquí ya en el fondo la idea que desarrollará más tarde con el concepto de "correlato" (92).

Al introducir la idea de "correlato", Pannenberg avanza un paso más en el "camino de vuelta" hacia la idea de Dios. Es lo que sucede en el contexto de sus investigaciones sobre el lugar de la teología en el concierto de las ciencias cuando le reconoce a la temática de la totalidad en cuanto tal "un rasgo más fundamental que a la problemática de la historia" (93). Fueron los problemas hermenéuticos con los que se enfrenta en dicho contexto los que le llevaron -como hemos visto- a la idea de la totalidad de sentido y, con ella, a plantearse más a fondo la pregunta por la unidad del ser. Entonces profundiza también, con Heidegger (Identidad y diferencia), en la cuestión de la "unidad unificadora" (94), una pregunta implícita ya en el "muy problemático concepto de "totalidad de la realidad" (95).

Analizando el carácter problemático de la idea de totalidad, Pannenberg pone en claro su utilidad teológica como mero "correlato" de la idea de Dios. No podemos atender aquí prácticamente más que al resultado de su argumentación al respecto. Por un lado, le interesa mucho dejar claro que el "camino de vuelta" desde la idea de totalidad a la idea de Dios no puede ser confundido con "una prueba rigurosa de Dios" (96). Pero, por otro, no es menos importante para él subrayar que ahí es donde se encuentra el "acceso metódico" (97) de la teología a la idea de Dios.

La relación entre parte y todo implícita en el concepto de totalidad exigiría que "el todo no pueda ser pensado como autoconstituyente", pues las partes no pueden ser deducidas de él. Por el contrario, el todo depende de alguna manera de las partes, sin las cuales no sería el todo; el todo son sus partes. De modo que no es lo mismo el todo que lo absoluto y, en consecuencia, que Dios. Así es como se le plantea inevitablemente a la filosofía la cuestión de Dios como instancia diversa del todo de lo finito que pueda fundamentar su unidad como todo: es la idea de la "unidad unificadora". Ahora bien, esta es una cuestión para la cual "la subjetividad del pensamiento" o, como le gusta expresarlo a nuestro autor, "el saber anticipativo acerca del todo" (98) no puede "concebir" una respuesta realmente adecuada. Un indicio de ello se encuentra ya en el hecho de que el concepto de todo, sin perjuicio de lo que acabamos de decir acerca de la relativa independencia de sus partes, implica también que estas, a su vez, solo pueden ser pensadas en referencia a aquel,

(91) Cf. ibíd., 67.

(92) Cf. Ein theologischer Rückblick auf die Metaphysik, 28ss. "La correlación significa, en la perspectiva de Troeltsch, que cada evento se sitúa en un tejido de causalidades recíprocas que le insertan en el conjunto de la realidad. Para Pannenberg, la encarnación significa que la acción de Dios se localiza en las correlaciones de la historia humana y no en un 'heilsgeschitliches Ghetto"" (F. Lienhard, W. Pannenberg, 342; la expresión ghetto histórico-salvífico se encuentra en alemán en el texto francés).

(93) Theologie als Wissenschaft. Ein Gespräch, 100.

(94) Cf. Erwägungen zu einer Theologie der Religionsgeschichte, 286.

(95) Wissenschaftstheorie, 307.

(96) Die Bedeutung der Kategorien "Teil" und "Ganzes", 94.

(97) Cf. ibíd., 96.

(98) Ibíd., 100. 
es decir, que carecen de autonomía lógica. Lo cual relativiza la argumentación que conducía a la cuestión de la unidad unificadora: no se encontrará por este camino una respuesta acabada a la cuestión de la realidad de Dios; pero basta de momento con haber dado con un lugar - un ámbito de inserción, como pide Ladrière a la teología- en el que la idea de Dios puede ser introducida en el discurso en una relación muy determinada con la experiencia del mundo (99).

En efecto, si la experiencia general de sentido implica una "totalidad de sentido" y esta, por su parte, una instancia una y única capaz de darle unidad, parece que la temática hermenéutica conlleva la temática religiosa. Porque, en medio de todas las discusiones sobre la idea de Dios, si algo hay incontrovertido, en opinión de nuestro autor, es que el mínimo para pensar con sentido que sea "Dios" es hacerlo como el poder sobre todo lo que existe, en concreto, como el poder unificador del ser (a estas "condiciones mínimas" [Minimalbedingungen] ha de dar cuenta una teología que pretenda ser tomada en serio; así continúa siendo posible un "concepto marco" [Rahmenbegriff] (100) filosófico de aquello a lo que justificadamente podemos llamar Dios). Y a una instancia así abocan los análisis hermenéuticos. De modo que desde el centro de la hermenéutica misma Pannenberg cree que se puede llegar a introducir la idea de Dios de modo coherente y armónico, sin "violencia" dogmática ninguna (101). Valga subrayar la vehemencia con que nuestro autor se expresa en relación a esta idea: "Pero a pesar de todas las demás disputas, lo que ha permanecido invariable hasta hoy respecto del concepto de Dios es que mientras no se le haya pensado como la unidad unificadora de todo lo que existe, no se ha pensado a Dios como Dios. Esto hace inevitable la implicación de la teología en los problemas de la metafísica" (102). Y, desde el punto de vista de la hermenéutica, es especialmente significativo para nuestra argumentación la siguiente aseveración de Pannenberg: "Pero a la pregunta por la realidad en su totalidad va unida inevitablemente la pregunta por la posibilidad de dicha totalidad, la pregunta por la unidad unificadora de la misma. No es necesario que esta cuestión aparezca desarrollada terminológicamente como pregunta por Dios, pero, objetivamente, no se trata en realidad de otra cosa" (103).

Es evidente que la idea de Dios a la que se llega así no responde todavía sin más a la realidad del Dios del cristianismo. No es ni siquiera todavía una idea propiamente religiosa de Dios. Se trata de un concepto "abstracto", de un consenso mínimo para hablar de Dios. Es un punto de partida "abstracto" en cuanto se trata únicamente de proposiciones sobre la estructura básica del ser humano que no conducen más que a una definición "nominal" e "incompleta" (104) de la divinidad al estilo de "la realidad que todo lo determina" o "el misterio de la realidad que supera su finitud". Son definiciones todavía "abstractas" en tanto cuanto no atienden primeramente a un hecho que ellas mismas implican: aunque son definiciones logradas

(99) Cf. ibíd., 94ss.

(100) Systematische Theologie, vol. 1, 120.

(101) Cf. Die Krise des Schriftprinzips, en: Grundfragen systematischer Theologie, Gesammelte Aufsätze, vol. 1, 11 (La crisis del principio de Escritura, en: Cuestiones fundamentales, 15-26); Über historische und theologische Hermeneutik, 137s.

(102) Gottesgedanke und menschliche Freiheit, 63.

(103) Wissenschaftstheorie, 306.

(104) Cf. Systematische Theologie, vol. 1, 175. 378.426. 
solamente a partir de una análisis del ser del hombre, al hablar de un poder determinante de todo ser están presuponiendo que el hombre mismo está siempre afectado por ese poder, en "relación" a "trato vital" con él (105) (es decir, que el hombre se encuentra desde siempre en la experiencia de aquella realidad a la que se dirige su pregunta por su propio destino; es así como el análisis puramente antropológicofilosófico tropieza con el hecho de las religiones históricas, en las cuales los dioses se muestran como poderes distintos del hombre, aportando una respuesta a la pregunta qué es el ser humano en su ilimitada autotrascendencia. En las tradiciones religiosas se encuentra el hombre confrontado con la realidad de lo divino, que le sale al encuentro manifestándole su poder en determinados acontecimientos). Pero la función que le corresponde en el discurso teológico a esta "definición mínima" es, según Pannenberg, fundamental, porque posibilita la "mediación conceptual" (gedankliche Vermittlung) entre las ideas de mundo y Dios a través de la temática hermenéutica (106). Esta mediación es probablemente lo propio del planteo de nuestro autor frene a la aludida corriente jüngeliana y barthiana: “... sigue siendo completamente posible 'un concepto marco [filosófico] de aquello a lo que merecidamente podemos llamar Dios'. Si no se reconoce esta posibilidad renunciamos también a cualquier posibilidad de reclamar justificadamente para el lenguaje cristiano sobre Dios alguna validez general" (107).

La idea de la unidad unificadora implicada en la de la totalidad de sentido está, pues, lejos de ser una prueba de la existencia de Dios, pero le plantea al pensamiento la misma "tarea" que ocupa, en un contexto diverso, a las religiones.

\subsection{Las religiones históricas como el lugar de encuentro con la realidad de Dios en el que es tematizada, asumida y superada originariamente la idea de la divinidad con la que el hombre cuenta desde siempre (108)}

Pannenberg ha recurrido a la palabra "Dios" para dar provisionalmente nombre a la instancia unificadora de la realidad a la que le abocaban sus análisis hermenéuticos sencillamente porque, en un primer momento, esta es la palabra con ese contenido semántico de la que el lenguaje dispone; más concretamente: porque esa es la palabra de la que dispone el lenguaje religioso en nuestra tradición cultural. Y no se trataría de una apropiación filosófica indebida de la palabra fundamental de las religiones, sino más bien de un modo de poner en claro tanto la universalidad como la irreductibilidad de la temática religiosa.

Al definir la peculiaridad del fenómeno religioso, Pannenberg parte de la caracterización que del mismo hiciera Schleiermacher (en quien ve la figura clásica del empeño moderno por mostrar que la religión es constitutiva para la realidad del hombre) en la primera redacción de sus Discursos sobre la Religión. La experiencia religiosa era comprendida allí como la "percepción del Universo, es decir, de lo infinito y total en un contenido particular y finito" (109).

(105) Cf. Erwägungen zu einer Theologie der Religionsgeschichte, 283.

(106) Die Bedeutung der Kategorien "Teil" und "Ganzes", 96.

(107) Systematische Theologie, vol. 1, 120.

(108) Cf. Sinnerfahrung, Religion und Gottesfrage, 101-113.

(109) Ibíd, 107. 
Con esta obra, que a través de una recepción crítica ha sido muy influyente en la estructura formal de la obra pannenbergiana (110), Schleiermacher quiso mostrar que la religión es una parte esencial del ser del hombre. La base de su argumentación es, pues, la idea de que la totalidad de lo humano implica el desarrollo de todos sus aspectos. Este pensamiento condicionó la idea que Schleiermacher se formó de la educación, suscitando asimismo la pregunta por el lugar antropológico de la religión. Esta posee, según este pensador, una provincia propia, específicamente suya, en el "ánimo" (Gemüte), al lado del conocimiento y la praxis. Sobre ella descansa la aspiración de la religión a la autonomía en su coexistencia con ellas. Más allá de la distancia que Pannenberg pone entre su planteo y el de Schleiermacher, rescata el hecho que para este el objeto de la religión no es, primariamente, nada sobrenatural ni transmundano, sino el "universo", es decir, la totalidad de lo finito en la medida en que en ella está presente lo infinito. Lo infinito no trasciende lo finito, sino que está presente en él: "Lo finito existe solo por determinación de sus límites, los cuales deben en cierto modo ser cortados (herausgeschnitten) de lo infinito mismo". La religión es la conciencia de este estado de cosas. Esta última debe "ver lo infinito en todo lo finito y singular", "tomar lo singular como una parte del todo, lo limitado como una representación de lo infinito". Lo primero que debe observarse es que en todas estas afirmaciones los términos "universo", "todo" e "infinito", tienen evidentemente el mismo significado. Por otro lado, sin embargo, el todo es determinante para el significado de las partes. Estas son "definidas" por el todo, del que "son, en cierto modo, cortadas". Por ello, todo lo finito es una "representación" de lo infinito y del todo; y como tal representación, lo finito es nuevamente, "dentro de dichos límites", en sí mismo infinito. A la conciencia cotidiana "del hombre ocupado en sus razonamientos y quehaceres prácticos", el estar condicionado de lo finito por lo infinito y el todo, le está por completo oculto, pues toda su atención está concentrada en los objetos y circunstancias finitos. Su influjo ahoga la disposición religiosa incluso en los niños. Por eso es necesario que el universo "actúe" en nosotros para que podamos intuir lo infinito en lo finito y particular. "Toda intuición se origina en el influjo de lo intuido en quien intuye, en un acto original y autónomo de lo primero, que el segundo recibe, sintetiza y comprende después conforme a su naturaleza". Pero al mismo tiempo, toda intuición va enlazada a un sentimiento (Gefühl), porque el influjo experimentado tiene también que "producir un cambio en nuestra conciencia interna". La intuición y el sentimiento del universo -en los que consiste para Schleiermacher la esencia de la religión- son, pues, resultado de un "obrar" del universo en nosotros, acción por la que nos apercibimos de la presencia de lo infinito en lo finito. Para Schleiermacher, existe asimismo una correlación entre ese actuar del universo y la idea religiosa de Dios. Esta última no determina la esencia de la religión en cuanto tal, pero se forma en aquellos hombres que no pueden representarse el actuar del universo de otra manera que "en la forma de un ser libre". Así, pues, el que alguien "tenga un Dios para su intuición [del universo], dependerá de la dirección de su fantasía”, es decir, de qué sea para esta lo verdaderamente decisivo, si la conciencia de la libertad -en cuanto funda-

(110) Cf. Systematische Theologie, vol. 1, 110-117.152-158; Die religiöse Erhebung über das endliche Dasein zu Gott, Euntes Docete 2 (2001), 15-23. 
mento del obrar- o, por el contrario, la idea, propia del entendimiento, de una concatenación universal de causas.

Viendo en el "Universo" schleiermachiano el equivalente de su "totalidad de sentido" (111), le resulta sorprendente a Pannenberg la enorme cercanía a los análisis de la religión del teólogo berlinés que muestran los que Dilthey realizaría después sobre la experiencia de sentido (112). "Más sorprendente aún" sería la involuntaria coincidencia en la que se encuentran definiciones sociológicas de la religión del tipo de la Th. Luckmann (113), con lo que Schleiermacher pensaba al respecto. Son convergencias que no harían más que poner de relieve que "siempre que se trata temáticamente de la comprensión de la realidad en su conjunto, aun sin apelar para ello a Dios o a los dioses, se puede hablar de fenómenos de carácter religioso" (114).

En efecto, nuestro autor opina que la anticipación que se lleva a cabo en toda experiencia de sentido es "religiosa o cuasi religiosa" (115). Y que, más en particular, por proceder de una anticipación semejante, también es religiosa la base de la legitimación y de la unidad de una determinada sociedad. Pannenberg habla por eso de una "religión en sentido amplio" o de la presencia universal y "atemática" de la dimensión religiosa (116). Lo habitual, sin embargo, ha sido siempre el dato de las religiones históricas como formas concretas de concebir la presencia del Universo en lo particular que ofrecen una respuesta determinada a la pregunta por la constitución última del mismo, es decir, que no solo tematizan la cuestión de la totalidad de sentido, sino que además presentan un modelo de solución a la cuestión de su "unidad unificadora". De modo que, si recordamos que con la idea de "unidad unificadora" la filosofía se encuentra, en opinión de Pannenberg, con la idea de Dios, "las religiones y su historia (son) el lugar en el que acontece la percepción expresa de la manifestación que la realidad divina hace de sí misma en cada caso" (117). Pero ¿por qué "automanifestación”, por qué "realidad divina” y por qué "en cada caso"?

Si se trata de verdaderas respuestas a la cuestión de la unidad unificadora han de serlo como automostración hecha por esta misma. En primer lugar, como ya hemos apuntado, por causa de los límites que el pensamiento experimenta ante tal cuestión, una cuestión última para la filosofía en el fondo porque esta no puede ir más allá de la "lógica de la anticipación" que es propia de todo conocimiento humano. No puede ir más allá en el sentido de que el pensamiento no se puede entender a sí mismo como carente de todo presupuesto y, por tanto, como totalmente autoconstituido y comprehensivo. Por el contrario, lo que le es connatural es "dejarse dar de antemano aquello hacia lo que tiende anticipándolo". Ese "dejarse dar" es el que acontecería en las representaciones religiosas que precisamente por eso, en cuanto automanifestaciones de la realidad divina, no son sin más reductibles a ideas,

(111) Cf. Wissenschaftstheorie, 314, n. 616.

(112) Sinnerfahrung, Religion und Gottesfrage, 107.

(113) Cf. Wissenschaftstheorie, 314.

(114) Cf. ibíd., 204.

(115) Cf. ibíd., 204

(116) Cf. ibíd., 303. 306. 313s

(117) Anthropologie in theologischer Perspektive, 315s. 
sino que mantienen su originalidad al modo de un "suelo religioso" que precede permanentemente a la reflexión (118). El análisis de la experiencia del sentido daría testimonio de esta misma realidad al poner de manifiesto que "percepción del sentido" no es nunca, sin más, equivalente a "creación de sentido" (119).

En segundo lugar, la respuesta de las religiones ha de ser entendida como automanifestación de la divinidad por causa de la misma idea de Dios. Pannenberg insiste en que no es concebible un conocimiento adecuado del poder unificador de todo que se diera sin su intervención. Insiste nuestro autor en que "cualquier saber acerca de Dios fundado por un camino distinto del de la iniciativa propia de Dios eliminaría el concepto mismo de Dios" (120). Dicho "saber fundado" es aportado por la revelación histórica de Dios, que explicita y muestra como efectivamente activa y poderosa a aquella realidad divina de la que el hombre se había hecho un concepto abstracto. De ahí que el proceso de la revelación en la historia esté "de acuerdo con la forma de la prueba ontológica de Dios". Por eso tendría el concepto de Dios tanta importancia como punto de partida del discurso teológico; pues, aunque no sea más que eso, un punto de partida abstracto y provisional, asegura la relevancia objetiva de dicho proceso discursivo, ya que mostraría desde el principio del mismo que el Dios que se revela es algo más que un producto del capricho o de la subjetividad del hombre (121), en donde nuestro autor se inspira aquí expresamente en Hegel (122) (es notable el apoyo de Hegel a lo fundamental del argumento ontológico desde una concepción de la "razón" que no se identifica con la actividad disociante y meramente conceptualizadora del "entendimiento". Hegel considera, en la Enciclopedia, por una parte, obvia y "trivial" la diferenciación entre "ser" y "pensar", pero sostiene, por otra parte, frente a la crítica kantiana del argumento ontológico, que "se debería pensar en que, cuando el discurso versa sobre Dios, este es un objeto de tipo diferente de cien táleros". De aquí que solo en el caso de Dios, y no tratándose de nada "finito", se dé verdadera "unidad entre concepto y ser" [§ 51]. En todo caso, Hegel objetará por su parte a las tradicionales exposiciones del argumento ontológico el que en ellas se le conceda todavía una consistencia o verdad excesiva a lo "finito" frente al "infinito", cuando solo en este como en el "todo" reside la verdad [§ 193] (123)). De aquí la experiencia religiosa de la divinidad como algo originariamente personal (124).

Las religiones son, por todo ello, el lugar en el que la idea provisional o nominal de Dios con la que trabajan la teología o la filosofía se encuentra desde siempre asumida y superada (aufgehoben). Pretenden, como vemos no sin razones, ser el ámbito primario de encuentro explícito del hombre con Dios. Y no ya con una idea abstracta de El, sino con su realidad misma que le sale al encuentro. ¿En qué

(118) Cf. Cf. Über historische und theologische Hermeneutik, 152.

(119) Cf. Systematische Theologie, vol. 1, 160s.

(120) Anthropologie in theologischer Perspektive, 89.

(121) Cf. N. H. Gregersen, Einheit und Vielfalt der schöpferischen Werke Gottes. W. Pannenbergs Beitrag zu einer trinitarischen Schöpfungslehre, Kerygma und Dogma 45 (1999), 102-129, sobre todo 128-129.

(122) Cf. Metaphysik und Gottesgedanke, 28ss.

(123) Cf. Religion und Metaphysik, 53ss.

(124) Cf. Die Frage nach Gott, en: Grundfragen systematischer Theologie, Gesammelte Aufsätze, vol. 1, 381ss (La pregunta sobre Dios, en: Cuestiones fundamentales, 167-196). 
sentido habla Pannenberg, en este momento decisivo de su argumentación, de realidad en relación -de identidad y diferencia- a idea de Dios? (125). Para tratar de comprender algo mejor esta cuestión, me parece interesante volver sobre la reflexión que Pannenberg hace en torno al argumento ontológico en diálogo con Kant y con Hegel. Sin embargo, será necesario en el próximo párrafo hacer una breve alusión a la importancia formal del Argumento en Pannenberg y su dependencia de Anselmo, ya que nosotros pensamos que la estructura del argumento ontológico (la idea de Dios no puede pensarse como no existente sin contradecirse) se manifiesta como patrón de articulación de la antropología con la teología en la obra de nuestro autor (126).

El conocimiento de la realidad de Dios solo es posible por revelación, por automanifestación de Dios mismo. Es lo que sucede en las diversas "revelaciones" en las diversas experiencias y fenómenos religiosos, sin que se pueda todavía hablar de ellos como de la revelación de Dios. Esta ha acontecido anticipadamente en el destino de Jesucristo, permanece abierta y no permite hablar de Dios de una manera totalmente cerrada y conclusa. El Dios de Jesucristo sigue mostrando su divinidad -reinando- en la historia y sigue al mismo tiempo estando en juego en ella. Pero "estar en juego" (auf dem Spiel) (127) no significa solamente que un conocimiento definitivamente "probado" de la realidad no es esperable ni posible en esta historia. "Estar en juego" significa también la presencia ineludible del poder de Dios en el mundo. Es esta presencia, con la que el hombre se encuentra desde siempre confrontado en la estructura más profunda de su ser, la que hace posible una antropología que saque a la luz los rasgos religiosos del ser humano como elementos que le configuran de modo decisivo. Ahora bien, es necesario subrayar que si ni siquiera la automanifestación histórica de Dios permite un saber "probado" de El, menos aún podrá proporcionarlo la antropología (128). Los análisis antropológicos permanecen en un nivel de abstracción que no permiten en modo alguno el acceso a la realidad de Dios, pero sí que ponen de manifiesto la inexcusabilidad de la idea de Dios cuando tratamos de comprender a fondo al hombre y al mundo. Una vez asegurada así como necesaria la idea de Dios, el acceso a su realidad acontece siguiendo la dinámica formal del argumento ontológico: la existencia se seguirá del concepto de Dios. El concepto de Dios exige que, como todo, también el acceso a Dios esté determinado por Dios mismo, es decir, que nos remite al lugar en el que el conocimiento de Dios acontece gracias a su automanifestación.

Un discurso adecuado sobre Dios ha de tener, de esta manera, en opinión de nuestro autor, "la forma lógica del argumento ontológico" (129) en cuanto que, como acabamos de ver, ha de contar con una automostración de Dios. Pannenberg

(125) Con la idea de identidad y diferencia, tal como lo ha notado T. Schärlt (art. Differenz, en: A. Franz et al (ed.), Lexikon philosophischer Grundbegriffe der Theologie, Freiburg 2003, 85-87), se puede caracterizar la forma de pensar pannenbergiana, por lo que nos parece poco matizada la crítica que ha recIbído Pannenberg de presentar un hiato entre idea y realidad de Dios (de tipo kantiano), tal como por ejemplo lo señala, entre otros, W. Schluz (Sein und Trinität, St. Ottilien 1997, 423-502).

(126) Cf. por ejemplo, Metaphysik und Gottesgedanke, 20-33.

(127) Cf. Systematische Theologie, vol. 1, 341.

(128) Cf. Anthropologie in theologischer Perspektive, 70.

(129) Wissenschaftstheorie, 302. 
sigue en este punto a Hegel (y a Barth), que veía en el llamado argumento ontológico la síntesis formularia, de tipo filosófico, de la religión cristiana, de la religión de revelación. Pero, por otra parte, está de acuerdo con Kant en que sobre Dios no es propiamente posible más que una argumentación de tipo práctico (130). No es que le dé sin más la razón en su crítica del argumento ontológico. Por el contrario, aquí Pannenberg sí que es decididamente "hegeliano": según él, hay que mantener frente al filósofo de Königsberg por un lado que "la temática religiosa, en cuanto "consciencia de lo absolutamente verdadero", tiene en sí misma su fundamento y no recibe en modo alguno su legitimación solo de su relevancia práctica" (131) y, por otro lado, que este concepto -el de Dios-, a diferencia de cualquier otro, implica la existencia de lo conceptualizado (132). Ahora bien, esta implicación no puede ser, según nuestro autor, algo así como una prueba definitiva de Dios: desde el concepto de Dios no se puede deducir su existencia, sino tan solo, por así decir, disponerse o abrirse a su posible automostración (133). Esta sería la única posible "prueba" de Dios. No solo por todo lo que venimos diciendo sobre la necesidad de concebir el conocimiento de Dios como fruto de su auto-revelación. Pannenberg añade aquí además un matiz interesante que sitúa su postura en un punto medio entre Kant y Hegel: la idea de Dios antropológicamente mostrada como necesaria, podría carecer de verdad. ¿Qué quiere decir con esto?

Pannenberg sigue a Hegel en la preocupación por el punto de partida del discurso del argumento ontológico, que es la idea de Dios: si esta no se muestra de alguna manera como necesaria, el resto de la argumentación aparecería como carente de un fundamento objetivo. El punto de partida no puede ser arbitrario. Pero se distancia de él, volviendo a Kant, cuando observa que incluso una idea de Dios que fuera inevitable para el hombre en cuanto hombre podría ser una ilusión irremontable para él (134). Y es que el hombre no dispone de su verdad, porque esta se le sustrae una y otra vez desde su propio "futuro esencial" (Wesenszukunft) (135). Pannenberg interpreta, por eso, lo que Kant quería decir con la restricción de su argumento moral a una validez práctica, en el sentido de que ha de ser el encuentro histórico con la divinidad el que, en último término, verifique el discurso sobre Dios (136).

El encuentro histórico con la divinidad no se da nunca de una manera meramente privada, se encuentra siempre mediado de algún modo por las formas tradicionales e institucionales de las religiones (137). Las afirmaciones y las pretensiones que estas presentan sobre la realidad de la divinidad, y en nombre de ella, no son siempre las mismas, sino que difieren e incluso compiten entre sí. De modo que "en cada caso" -decía Pannenberg en la definición de religión que acabamos de recoger-, la automanifestación de Dios resulta diversa para la experiencia humana.

(130) Cf. Gottesgedanke und menschliche Freiheit, 25s.

(131) Ibíd., 82.

(132) Cf. ibíd., 15.

(133) Antwort auf Sauters, 176.

(134) Cf. Gottesgedanke und menschliche Freiheit, 15. 25.

(135) Cf. Wissenschaftstheorie 198; M. Dumas, Expérience religieuse et foi chrétiene, 319-320.

(136) Cf. Erwägungen zu einer Theologie der Religionsgeschichte, 284.

(137) Cf. Wissenschaftstheorie, 315, 321s; Systematische Theologie, vol. 1, 111ss. 
El "creyente" que se encuentra inmerso en una determinada tradición no tematiza este hecho; tanto menos cuanto más comúnmente aceptadas resulten las respuestas de su religión en un determinado momento cultural (138). Pero lo propio del discurso teológico es hacer expresamente lo que el creyente hace acaso solo de modo implícito: poner a prueba las afirmaciones de la tradición religiosa preguntándose por su verdad (139). De modo que la teología "tiene que tratar la tesis de la fe como una hipótesis que necesita ser confirmada" (140). Así pues, para la teología las afirmaciones de la(s) tradición(es) religiosa(s) tienen la función de una hipótesis "en su proceso de acreditación o no acreditación ante un modo de experimentar la realidad que ellas mismas han hecho posible" (141).

En resumen, las religiones históricas son el lugar social de encuentro con la realidad de Dios en el que es tematizada, asumida y superada originariamente la idea de la divinidad con la que el hombre cuenta desde siempre en una u otra forma y que le dispone a dicho encuentro. En este la realidad de Dios no es aprehendida de una vez por todas, sino que se nos da solamente al modo de una continua remisión a la experiencia del mundo ante la cual se ha de acreditar como realmente capaz de iluminarla y unificarla en su integridad. La acreditación se da de modo más o menos implícito en la vida del creyente, pero su comprobación desarrollada es tarea de la teología.

Pasemos, pues, a esbozar en el siguiente punto (4) el modo en el que, según Pannenberg, en la religión cristiana se lleva a cabo dicho proceso de tematización, asunción y superación. Ahí reseñaremos los criterios que -en su opinión- guiarían el proceso teológico de acreditación de la tradición judeo-cristiana.

\section{LA RELIGIÓN JUDEO-CRISTIANA: EL LUGAR DE ENCUENTRO CON LA REALIDAD DE DIOS EN EL QUE ES TEMATIZADA, ASUMIDA Y SUPERADA LA IDEA DE LA DIVINIDAD}

\section{1. El conocimiento de Dios desde la alteridad histórica (142)}

El rechazo que ha hallado el intento pannenbergiano al tratar de comprender la revelación de Dios como coextensiva con la historia del mundo se debe en buena parte -opina el mismo Pannenberg- a que la idea de historia que domina hoy, incluso en los ámbitos teológicos, es uno de los productos señeros del proceso de emancipación de la cultura moderna de sus raíces cristianas. Si se entiende la historia secularizadamente, solo como "escaparate de los hechos y de los dolores de los hombres" (143), es natural que no se la considere capaz de revelación de Dios e

(138) Wissenschaftstheorie, 325.

(139) Cf. Gottesgedanke und menschliche Freiheit, 70.

(140) Wissenschaftstheorie, 298.

(141) Antwort auf Sauters, 176.

(142) Cf. K. Koch, Der Gott der Geschichte. Theologie der Geschichte bei Wolfhart Pannenberg als Paradigma einer philosophischen Theologie in ökumenischer Perspektive, Mainz 1988; G. Accordini, La Rivelazione di Dio come storia e come atto. Scenari e codici nella teologia di W. Pannenberg. Milano 2002.

(143) Stellungnahme, 321. 
incluso como opuesta a ella (144). Pero como "la historia no es secularizable sin que se la disgregue, sin que pierda su unidad" (145), la concepción antropocéntrica de la historia no ha conducido solo a su exclusión de la teología como cuerpo extraño interpuesto entre Dios y el hombre, sino también al intento bastante generalizado de sacudirse la "prepotencia" (146) de todo ensayo de reconstrucción del proceso de la historia, por ser una tarea sentida como amenaza de lo individual y de lo concreto.

La teología no puede contentarse con esta "pérdida de la historia". No solo por mantenerse presente en una de las grandes discusiones que dividen hoy los espíritus, sino porque su propio punto de partida se lo impide. No le es posible a la teología de la religión del Dios de la Alianza y de la Encarnación dar por buena "una concepción teológicamente neutral de la historia" (147) que conlleva, a la postre, el abandono del interés por la historia. Se pondría en cuestión a sí misma, su propia identidad peligraría.

En efecto, si el descubrimiento de la realidad como historia fue hecho posible por la experiencia del Dios bíblico, un retroceso o un cambio sustancial en este punto no dejaría de afectar el nervio mismo de la religión bíblica. Y a la inversa, una confirmación de aquel descubrimiento sería un elemento central del proceso de acreditación de la idea judeo-cristiana de Dios. Decidir esta cuestión es una tarea evidentemente compleja. Como hemos visto ya, Pannenberg cree que el trabajo hermenéutico conlleva como elemento propio la referencia a un proyecto de historia universal. Esta exigencia no puede ser satisfecha por una concepción de la historia que pretendiera sustituir totalmente a la teología de la historia que está en el origen de la idea misma de historia. En este sentido, ni la huida desde lo histórico hacia la "historicidad" existencial o hacia una "suprahistoria" exclusivamente religiosa, ni la soledad del hombre como actor único de la historia constituyen alternativas válidas a la concepción bíblica de la realidad como historia (148). Estos son los dos flancos principales ante los que se desarrolla la teología de Pannenberg.

La experiencia religiosa del Dios creador que elige a su pueblo dirige la atención del creyente hacia el devenir y hacia el cambio en el mundo como expresión de la actuación poderosa y providente del Creador y Salvador. He aquí la peculiaridad de la religión de Israel en medio de la historia de las religiones: no encuentra a su Dios solo en unos tiempos originarios presuntamente plenos e inmutables, sino cada vez más en el futuro al que le remiten sus promesas y las correspondientes experiencias de su fidelidad en los acontecimientos releídos como cumplimiento de aquellas promesas, aun en medio de la novedad más inesperada. De esta manera, el pensamiento israelita se fue liberando, aunque nunca fuera del todo, del esquema mítico de un tiempo originario determinante (149). Así es como la historia deja de ser meramente el lugar de lo amenazante para convertirse en el medio de la automanifestación y del conoci-

(144) Cf. ibíd., 312ss.

(145) Ethik und Ekklesiologie. Gesammelte Aufsätze, Göttingen 1977, 21 (Etica y eclesiología, Salamanca 1986).

(146) Heilsgeschehen und Geschichte, 41.

(147) Art. Geschichte/Geschichtsschreibung/Geschichtsphilosophie, VIII. Systematisch-theologisch, en: G. Krause et al (ed.), Theologische Realenzyklopädie, vol. 12, Berlin-New York 1984, 660.

(148) Cf. Systematische Theologie, vol. 1, 252ss.

(149) Cf. ibíd., 185ss 
miento de Dios. La historia es el "precipitado de la actuación de Dios" (150), es la historia de Dios (151). Aquí se puede rastrear la gran aportación de G. von Rad, profesor de Pannenberg en Heidelberg, quien, frente a la "pérdida de la historia" de la teología kerygmática, puso de manifiesto que es en la historia única de Dios con su Pueblo donde hay que buscar el nexo entre Antiguo y Nuevo Testamento (152) (se daría así una "teología de la historia"). El acontecimiento de Cristo supondrá, como veremos en seguida, una profundización de este camino de Israel.

Es importante subrayar que la historia concebida como historia de Dios, lejos de ser un contrapunto obstaculizador del conocimiento de Dios es, según Pannenberg, la "mediación" (153) con la que Dios se pone creadoramente en relación con su creación llevando adelante en ella su voluntad salvífica escatológica (154): "Ante el cuestionamiento moderno de la fe tradicional en Dios y, por supuesto, la fe en la palabra inspirada de Dios de la Biblia, la idea que Dios se revela a sí mismo actúa como mediación entre Dios y este mundo que se aparta de El ¿Cómo? Con la concepción de una historia que, a través de juicio y reconciliación, transforma a este mundo en el lugar de reinado de Dios y de revelación definitiva de su gloria gracias a la afirmación escatológica de su voluntad creadora" (155). "La exposición sistemática de la doctrina cristiana toma al mundo, al hombre y la historia como expresión y testimonio de la divinidad de Dios. La historia del hombre y del mundo constituye para ella el medio en el que se da la oposición del hombre a Dios y también el paso hacia su propia transformación en testimonio de la divinidad" (156). Los escritos bíblicos son documentos de un camino en el que diversos acontecimientos se han ido convirtiendo en "ocasiones para la esperanza", para la confianza en el futuro a veces imprevisible de Dios (157). Desde esa confianza se va descubriendo la unidad de todo acontecer como fundada en la fidelidad divina: Dios no abandona tampoco a la creatura que se cierra a su oferta de alianza. La conciencia del mundo como historia y de su unidad procede, pues, de "un conocimiento positivo" (158) de la actuación creadora de Dios, pero no excluye el elemento de fracaso del ser finito que se cierra en sí mismo (por cierto, no sin referencia a Agustín) (159).

El Dios de la Biblia se muestra como el Señor único de la historia. Es su actuación libre la que ha abierto y abre ante el hombre el horizonte del futuro. Aquí está la raíz de la experiencia de Dios como "persona". Y aquí está el motivo de la permanente función histórico-teológica de la "subjetividad de Dios como base de la libertad humana" (160). Por lo demás, la aporía que plantea la idea del sujeto que se

(150) Glaube und Wirklichkeit. Kleine Beiträge zum christlichen Denken, München 1975, 113s.

(151) Cf. Heilsgeschehen und Geschichte, 34ss.

(152) Cf. ibíd.

(153) Der Gott der Hoffnung, 396.

(154) Cf. Systematische Theologie, vol. 3, 569ss.

(155) Offenbarung als Geschichte, Kerygma und Dogma Beiheft 1 ( $\left.{ }^{5} 1982\right)$, V (La revelación como historia, Salamanca 1977).

(156) Systematische Theologie, vol. 1, 69.

(157) Cf. Der Gott der Hoffnung, 396.

(158) Cf. Erfordert die Einheit der Geschichte ein Subjekt?, en: R. Koselleck et al (ed.), Geschichte, Ereignis und Erzählung (Poetik und Hermeneutik V), München 1973, 486.

(159) Stellungnahme, 486; cf. Tod und Sünde, Berliner Theologische Zeitschrift 20 (2003), 103-110.

(160) Erfordert die Einheit der Geschichte ein Subjekt?, 489. 
constituye a sí mismo, se replantea cuando se pretende sustituir la soberanía del Dios de la historia por la del "género humano" que se realizaría a sí mismo en ella. Pero la actuación de Dios, que le muestra como poder unificador de la historia, no puede concebirse hoy demasiado antropomórficamente al modo de intervenciones aisladas y directamente aprehensibles como acciones de Dios; no tiene, en este sentido, "carácter sobrenatural" (161). "Tampoco la subjetividad de la actuación histórica de Dios puede hacerse valer ya inmediatamente, sino solo mediada por el proceso de tradición y recepción y, por tanto, en relación con la experiencia humana de la historia" (162).

Es la tradición la que refiere los "motivos de esperanza" del pasado que fundamentan nuevas promesas de futuras actuaciones liberadoras de Dios. El acontecer mismo irá mostrando el modo en que su realización se convierta en ocasión de nuevos motivos de esperanza. He aquí por qué "la historia se realiza concretamente como historia de tradición" y por qué Pannenberg cree que "el concepto de historia de tradición es el más profundo concepto de historia en absoluto” (163).

La religión bíblica, al tematizar el devenir histórico como material propio, abriendo así el camino del mito a la historia, desvela al hombre la historicidad de su experiencia de Dios. Una historicidad que está atemáticamente presente en toda experiencia de Dios. El desvelamiento se consuma cuando la fe cristiana llega a introducir a Dios mismo en la historia de los hombres.

\subsection{Jesús, uno con Dios como el Hijo: la presencia del futuro de Dios en su persona}

\subsubsection{La llegada de lo definitivo acontece en Jesucristo como anticipación}

La idea cristiana de Dios no es tan diversa de la de Israel que se hiciera necesario considerar al cristianismo como una nueva religión. De lo que habla Pannenberg es de "un cambio desde dentro" de la propia tradición judía. El cambio consiste en una profundización y radicalización tal de la comprensión de la historia como medio de la automanifestación de Dios, que el pensamiento y las representaciones míticas quedan totalmente supeditadas a la historia de Dios. Esta se focaliza ahora en una historia muy particular, la del hombre Jesús de Nazaret, cuya actuación y destino son interpretados, en el contexto de la tradición del Pueblo de la Alianza, como el cumplimiento, de nuevo desconcertantemente inesperado, de las promesas de Dios sobre su manifestación definitiva por medio de su acción liberadora. El cumplimiento de la esperanza del Pueblo que aconteció en Jesucristo supone un desvelamiento definitivo de la historicidad de la experiencia religiosa, es decir, de su dependencia de la manifestación histórica de Dios, porque lo que en realidad significa es que la historia no es solo de Dios ni solo del hombre, sino una historia "divino-humana": que Dios y el hombre están implicados -evidentemente de diversa manera- en una misma historia. Veamos brevemente qué quiere decir esto pasando

(161) Cf. ibíd., 488.

(162) Ibíd.

(163) Heilsgeschehen und Geschichte, 88. 
sucesivamente revista a la historización de Dios y del hombre que conlleva el concepto cristiano de Dios y a las consecuencias que ello tiene para la comprensión de la historia.

Aunque parece evidente que el Dios que se descubre en Jesucristo no puede ser pensado sin la historia de Jesús, es esta una tarea que está aún casi por hacer. La teología tradicional, al perder, por un lado, ya muy pronto la idea de la irrupción próxima del Reinado de Dios, y al entrar en diálogo, por otro, con la manera atemporal griega de pensar la divinidad, no llegó a ser consciente del todo de lo que significaba para el ser mismo de Dios la afirmación central de la tradición cristiana de que en Jesús se había dado la revelación definitiva de Dios. Una afirmación así prohíbe hacerse un concepto más o menos acabado de Dios que no sea ganado precisamente en la cristología. En cambio, la que Pannenberg llama "cristología de encarnación" comenzaba su tarea sabiendo ya por el "tratado de Dios" que Dios era el que había de hacerse hombre en Jesucristo. Se perdió de vista el contexto religioso histórico que hizo posible las afirmaciones cristianas de la revelación y de la encarnación de Dios en Jesucristo. De ahí que se olvidara también la historización de la comprensión de Dios mismo que ellas suponían (164).

La presencia de Dios en Jesucristo, que hace legítimo que se hable de la encarnación de Dios en él o, a la inversa, de que Jesús es uno con Dios como el Hijo, es la presencia del futuro de Dios en su persona. Así fue entendido el acontecimiento de la resurrección en el contexto de las tradiciones apocalípticas judías. Lo que se esperaba como elemento de la irrupción del Reinado de Dios en este mundo y, por tanto, como fin de la historia, ha acontecido ya de manera inesperada solo en aquel hombre. El testimonio de su vida y predicación sobre la llegada amorosa de Dios con él se ve así confirmado (165). La llegada de lo definitivo acontece, pues, en Jesucristo como mera anticipación. Y por eso no solo no queda cerrado el futuro, sino que la presencia de lo definitivo en Cristo da paso, como nueva e insuperable promesa, a un nuevo proceso histórico en el que ahora el mismo Dios, que constituye su unidad, se encuentra "personalmente" implicado. El Dios de la historia está él mismo en juego en la historia.

Pero el acontecimiento del fin de la historia en Jesucristo significa también, además de la historización de Dios, el descubrimiento del hombre como historia (166). Los criterios orientadores sobre lo que el hombre sea en realidad no hay que buscarlos ya en los arquetipos del tiempo original presuntamente incontaminado todavía. Porque la esencia verdadera del hombre no está en el primero, sino en el "segundo Adán".

Antes de analizar más en profundidad el término anticipación en el próximo punto, es necesario subrayar, para una mejor comprensión de las relaciones fundamentales entre la temática de la resurrección -central en su pensamiento (167) - a la cual hemos aludido y el planteo hermenéutico general de Pannenberg, algunas ideas

(164) Cf. Systematische Theologie, vol. 1, 283ss. 360s; Systematische Theologie, vol. 2, 365ss; Geschichtliche Offenbarung Gottes und ewige Trinität, Kerygma und Dogma 49 (2003), 236-246.

(165) Cf. Über historische und theologische Hermeneutik, 157; Systematische Theologie, vol, 2, 385ss.

(166) Cf. Anthropologie in theologischer Persperktive, 482.

(167) Que el tema de la resurrección es clave en la obra de Panneberg ha sido subrayado con vehemencia, entre otros, por G. Essen, Historische Vernunft und Auferweckung Jesu, Mainz 1995. 
de la forma como aquella temática le permite a nuestro autor la fusión de horizontes a partir de la idea de espera, tanto en la época de Jesús como hoy, y repensar así las implicancias antropológicas de la hermenéutica teológica.

Una vez fijado el significado de la resurrección, Pannenberg intenta situarlo en el marco de las expectativas de entonces y de hoy. Es decisivo el cuadro de pensamiento apocalíptico-escatológico que Pannenberg discute después respecto a la precomprensión antropológica actual. Aquí podemos distinguir varios puntos: a) el lenguaje de resurrección es un lenguaje metafórico mediante el cual se alude, a partir de un punto de vista de la experiencia (el despertar del sueño) a una realidad que se escapa a la experiencia: "La realidad en que se piensa y el modo en que se habla de ella son esencialmente distintos" (168); b) la representación neotestamentaria no es la que cabría obviamente esperar, a saber, a la manera de una reanimación de un muerto. En Pablo, resurrección significa la vida nueva de un cuerpo nuevo y no el retorno a la vida en el cuerpo muerto. No se trata, pues, de una resurrección general, una para la salvación y otra para la condenación, sino de la participación de todos los hombres en la salvación; c) por eso la resurrección de Jesús de entre los muertos es rigurosamente distinta de la esperanza general para el futuro y de las vueltas a la vida que nos relatan las literaturas antiguas o de la resurrección de los muertos que el mismo Jesús ha realizado. Se plantea, pues, el problema de dónde han tomado Pablo y la comunidad primitiva esta "representación" de la resurrección de los muertos; d) la tradición apocalíptica de la esperanza para el futuro propia del hebraísmo posterior al exilio es el terreno donde germina esta representación. Esto permitió a Pablo y antes a los discípulos de Jesús calificar el evento singular que les sucedió como algo perteneciente al género de vida de la resurrección; e) es significativo que el kerygma misionero de los orígenes haya traspuesto la expectativa apocalíptica también a las nuevas comunidades procedentes del paganismo. Por eso, la expectativa apocalíptica subsiste también para la Iglesia de los cristianos étnicos en sus rasgos principales (169).

La cuestión hermenéutica esencial hoy es, según nuestro autor, la que se pregunta si este horizonte previo de conocimiento tiene algo que ver con una precomprensión antropológica universalmente accesible: "Si el destino de los hombres individuales no se agota en su relación con la sociedad, entonces no se puede eludir el problema de si el individuo puede esperar más allá de la muerte un complemento de su destino humano, o si hay que desechar, por no tener sentido, el interrogante sobre el ser-hombre del hombre en absoluto" (170). La filosofía moderna de la esperanza (por ejemplo Bloch) ha recuperado el contenido oculto en la espera apocalíptica, demasiado oscurecido en la tradicional teoría filosófica dualista de la inmortalidad del alma. Así es posible también hoy una continuidad con la esperanza apocalíptica (171).

(168) Grundzüge der Christologie, Gütersloh 61982, 70 (Fundamentos de cristología, Salamanca 1974).

(169) Cf. Systematische Theologie, vol. 2, 391-393.

(170) Grundzüge der Christologie, 80.

(171) Cf. Systematische Theologie, vol. 2, 393-394. 


\subsubsection{Anticipación: punto neurálgico de la argumentación de Pannenberg.}

Antes de pasar a ver cómo la idea cristiana de Dios y del hombre conlleva también una profundización en la comprensión de la historia que, sin dejar de ser historia de Dios, es también historia del hombre, "divino-humana", hagamos todavía algunas observaciones sobre la idea de anticipación.

El concepto de anticipación que es el punto clave de la argumentación sistemática de Pannenberg, tiene en su cristología la doble función de, por un lado, subrayar lo específico e irrepetible del acontecimiento de Cristo y, por otro, de poner en relación la idea particular del Dios que se revela en dicho acontecimiento con la idea de la divinidad implícita, al menos, en la experiencia humana en general. La estructura anticipativa de la realidad en general hace comprensible el mensaje cristiano: este no se refiere simplemente "a otro mundo". Y el mensaje cristiano, por su parte, ofrece una explicación de aquella estructura cuya fuerza integradora de los diversos elementos de la experiencia no solo ha posibilitado el descubrimiento de ese modo de ser de la realidad, sino que sigue siendo el criterio básico para el enjuiciamiento de su validez actual. Por eso es muy importante percatarse del modo particular en el que en Jesucristo se da la anticipación del fin: "El mensaje pascual cristiano responde al fundamental carácter proléptico de la historia de Jesús en cuanto que, como predicación de una acontecimiento particular situado en un pasado histórico, está, sin embargo, presuponiendo la universalidad de una transformación y consumación de la realidad del hombre y de su mundo, pendientes en el futuro" (172).

El lugar original de la idea de anticipación en la teología de Pannenberg es la cristología (173). El mismo dice que introdujo esa categoría "para describir la estructura peculiar de la historia de Jesús" (174). Pero también es verdad que se puso bien pronto a investigar "las implicaciones ontológicas, gnoseológicas e históricofilosóficas de la estructura peculiarmente anticipatoria del comportamiento y del destino de Jesús de Nazaret" (175). Pannenberg cree haber llegado a mostrar que la comprensión proléptica del acontecimiento cristológico no es un caso absolutamente extraño y sin paralelos, sino que "converge" (176) con las intuiciones de la filosofía que considera la prolepsis como "momento estructural del conocimiento, del lenguaje y también del ser de los seres en su temporalidad" (177) (en este contexto nuestro autor coincide con Rahner y los criterios de este último para una recta hermenéutica de la escatología cristiana con fundamentación antropológica, en donde se produce ese momento de convergencia entre escatología y esperanza humana) (178). La temática hermenéutica -dentro de la cual, como veíamos, aparece ya el problema de Dios- y la teología cristiana tienen aquí el lugar en el que pueden dialogar y aprender una de la otra. La tarea hermenéutica no es extraña a la teología del Dios de la

(172) Ibíd, 393; cf. Systematische Theologie, vol. 3, 573ss.

(173) Cf. Heilsgeschehen und Geschichte, 29. 42ss; ver también, M. Fraijó, Wolfhart Pannenberg: fe y razón, en: id., Dios, el mal y otros ensayos, Madrid 2004, 284ss.

(174) Stellungnahme, 331.

(175) Über historische und theologische Hermeneutik, 151s.

(176) Cf. ibíd., 152.

(177) Stellungnahme, 332.

(178) Cf. Systematische Theologie, vol. 3, 585ss. 
historia. Y, a la inversa, la irreductibilidad de la peculiar historia de Jesucristo será un reto y una enseñanza continua para aquella.

La estructura proléptica de la historia de Jesucristo, tanto por su forma como por su contenido, no es un caso nivelable con otros. En su contexto históricotradicional el destino de Jesucristo significa algo más que un reflejo anticipado de la realidad definitiva. Cristo es una "anticipación real" (179) de la salvación escatológica en el sentido de que en él se da una "participación plena de la realidad de la vida escatológica" (180), puesto que es ya "el futuro mismo el que acontece" (181) en su historia. Es esta comprensión fuerte de la idea de anticipación la que exige hablar de la acción de Dios como instancia unificadora interna del acontecer.

Al terminar este punto es necesario realizar aquí unas precisiones, pues quizá unos de los flancos de la teología de Pannenberg que ha recibido mayores cuestionamientos (182) ha sido su afirmación que la anticipación es una forma de presencia de la verdad definitiva y del significado permanente, pero unido por una trama de lo provisorio. Pannenberg valora que se entienda su acentuación de la presencia de lo anticipado en el acto de la anticipación. Sin embargo no está de acuerdo con la crítica que se le ha formulado, de acentuar tanto la diferencia entre ambos, que se llegue a contraponer el don de la presencia regalada en anticipado por Dios en su revelación histórica con el concepto de anticipación, como si se hubiese olvidado aquello sobre la presencia de la verdad anticipada en el acto de la anticipación o bien en un acontecimiento comprendido como anticipación. Además de ello, es un error, subraya Pannenberg, atribuirle una teoría anticipatoria de la verdad: es cierto que pertenece a la lógica de las afirmaciones el que ellas anticipen la verdad de lo afirmado, pero la verdad misma no es anticipatoria. En lo que hace a la teoría de la verdad, nuestro autor señala que ha defendido una teoría de coherencia de la verdad, pero no una estructura anticipatoria del mismo concepto de verdad (183).

Lo dicho en el párrafo anterior caracteriza también, a juicio de nuestro autor, la situación de la fe en contraposición a la visión escatológica. En el acto de la fe nos atenemos a la verdad definitiva de Dios, pero la confirmación definitiva de nuestra fe vendrá solo después de la realización escatológica, cuando veamos lo que hemos creído. La conciencia de la provisoriedad de nuestro conocimiento de Dios en las situaciones de una historia aún no acabada tiene, con seguridad, una cierta analogía y conexión con la propia diferenciación respecto de Dios, a la que nos obliga nuestra condición de criaturas y que se realiza en la relación de Jesús hacia el Padre en diferencia con aquello que la Biblia nos dice respecto del comportamiento de los primeros seres humanos, y que en esto pecaron: que quisieron ser como Dios. La analogía radica en la conciencia de la diferencia respecto a Dios. Pero mientras que, en el caso de la anticipación, el momento de la diferencia aparece como cualificación limitante de la pretendida posesión de la verdad o conciencia de sentido, en el caso de la autodiferenciación personal, como en el volverse hacia la Trinidad, consiste en una

(179) Offenbarung und "Offenbarungen" im Zeugnis der Geschichte, en: W. Kern et al (ed.), Handbuch der Fundamentaltheologie. Traktat Offenbarung, vol. 2, Freiburg 1985, 102, n. 37.

(180) Stellungnahme, 335.

(181) Offenbarung und "Offenbarungen", 97.

(182) Cf. a modo de ejemplo, M. Schulz, Sein, 433ss; K. Vechtel, Trinität, 240 ss.

(183) Cf. Geschichtliche Offenbarung, sobre todo 243 ss. 
unidad dialéctica entre diferencia y unidad. Por lo pronto, la diferencia está en primer plano, pero en la relación con Dios es el reconocimiento de la diferencia la condición de posibilidad de la comunión con Él. En la autodiferenciación del Hijo respecto al Padre, la comunión con el Padre implica dialécticamente el reconocimiento de la diferencia, por consiguiente de la superioridad del Padre, y de la correspondiente praxis de obediencia al Padre. En las relaciones trinitarias la comunión con las otras personas en el acto de la autodiferenciación no está anticipada sino implicada. De allí que tampoco es correcto, según Pannenberg, decir que Jesús anticipó en su autodiferenciación respecto del Padre su propia identidad de Hijo. Lo correcto es, mucho más, que su autodiferenciación del Padre implica que él es el Hijo, cuya filiación se corresponde completamente con la paternidad de Dios (184).

\section{3. La verdad del sentido de la historia: el encuentro de la humanidad con Dios en Jesucristo}

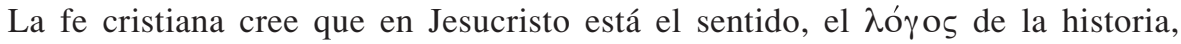
porque en él se ha dado el encuentro definitivo entre Dios y el hombre (185). Ya hemos visto cómo las religiones no pretenden sin razón que el acceso a la divinidad ha de darse como encuentro. ¿Cuáles son, pues, los rasgos centrales del "encuentro" cristiano que dan base a su pretensión de definitividad? Vamos a distinguir su forma de su contenido, siguiendo la indicación de Pannenberg mismo respecto de la peculiaridad de la prolepsis cristológica. Y así es como surgirá ante nuestra vista la comprensión cristiana del sentido de la historia como acción autorreveladora de Dios.

"El misterio divino se ha revelado en toda su riqueza insondable en el Dios del Reino venidero anunciado por Jesús" (186) porque las experiencias de Dios que la humanidad va haciendo en el curso del tiempo no se oponen ya necesariamente a aquel acontecimiento revelatorio. Este está abierto desde sí mismo al futuro y a lo nuevo y, así, es realmente capaz de revelar al Dios infinito sin cosificaciones finitizantes. La dimensión de futuro del hecho de Jesucristo se mantiene también después de la pérdida de la fe en la llegada inmediata del Reino bajo la forma de la espera de la venida gloriosa del mismo Señor. Lo importante entonces es que el Juez escatológico será Él mismo, es decir, que el futuro, en medio de su novedad, no hará más que poner de manifiesto de modo universal el rostro y los planes de Dios revelados prolépticamente en Cristo.

A esta forma de entender la automanifestación de Dios en su encuentro con el hombre Jesús como anticipación de su revelación escatológica, le corresponde una comprensión específica del contenido de la idea misma de Dios. Frente al Dios griego, al que se concibe como separado del devenir mundano, apático, y frente al Dios del Antiguo Testamento, en quien se ve al Señor todopoderoso sobre el acontecer de la historia, el Dios uno con el hombre Jesús está él mismo implicado en la historia. Hasta tal punto, que se puede decir que Dios "se realiza a sí mismo" con el

(184) Cf. ibíd.; Systematische Theologie, vol. 1, 58-132.365ss.

(185) Cf. Christologie und Theologie, en: Grundfragen systematischer Theologie. Gesammelte Aufsätze, vol. 2, 144; Systematische Theologie, vol. 2, 365ss.

(186) Cf. Systematische Theologie, vol. 3, 625ss. 
hombre, es más, que "la autorrealización de Dios y del hombre son idénticas" (187). Eso sí, aclara nuestro autor, esta idea de una "historia de Dios" no implica un "devenir de Dios en la historia", con lo que rechaza: “... la idea de un devenir de Dios en la historia, que imagina que el Dios trinitario no llegaría a ser realidad más que en la consumación escatológica de la historia como resultado del proceso histórico. Ante la experiencia histórica del hombre, las cosas aparecerán posiblemente de tal manera que la divinidad del Dios predicado por Jesús no se mostrará definitivamente hasta el momento de la consumación escatológica de la historia. Es más, puede que la divinidad de Dios no sea tampoco objetivamente pensable con independencia de que su reinado llegue a su plenitud... Pero, con todo, la consumación escatológica no será más que el lugar en el que se decida que el Dios trinitario es el Dios verdadero desde el principio, por toda la eternidad. No obsta en absoluto para ello que su existencia dependa de la consumación escatológica de su reino. Solo que habrá que explicar el significado constitutivo que tiene la consumación escatológica en la comprensión de dicha eternidad... ella [la consumación escatológica del reino del Dios predicado por Jesús] será la que revele de modo definitivo e irrefutable la divinidad de ese Dios decidiendo así la lucha entre el ateísmo y la fe: por fin, pero al mismo tiempo retroactivamente para toda la eternidad" (188).

La fundamentación cristológica de estas afirmaciones se articula en torno a la idea fundamental de que en la resurrección lo que se confirma como inalienable del ser mismo de Dios es su capacidad de autodiferenciación (189). Es esta una categoría -fundamental del pensamiento de nuestro autor-, ganada del mensaje y de la actitud de Jesús respecto al Padre: en él y no en sí mismo veía Jesús a Dios. Y le veía como acercándose paciente y amorosamente al hombre en su mensajero (190) (para evitar malentendidos, nuestro autor considera la autodiferenciación como una realidad que hay que leer en revelación histórica que es solo condición o presupuesto para la identidad de Jesús con Dios, en donde es necesario además que esta se muestre en la resurrección como obra de Dios mismo). La cualidad específicamente humana de aquel hombre estaba en esa su radical, confiada versión a Dios. De este modo, se encuentra a sí mismo como hombre y, para nosotros al menos, retroactivamente desde su resurrección, como el Hijo. "Bajo las condiciones del pecado" la diferenciación que Jesús hacía de sí mismo respecto del Padre pasa necesariamente por la cruz, es decir, por el fracaso temporal de su pretensión. A la luz de la resurrección este destino del Crucificado es a un tiempo la expresión suprema del inevitable fin del pecador y de su superación por el amor de Dios que toma sobre sí mismo aquel fin de muerte.

Dios encuentra su propia identidad cuando el hombre encuentra la suya. La historia es el camino de ese encuentro mutuo que, para la fe cristiana, ya se ha dado en Jesucristo; en él, de manera insuperable y, por tanto, irrepetible (191). La acción

(187) Cf. Christologie und Theologie, 144.

(188) Systematische Theologie, vol. 1, 359; cf. Systematische Theologie, vol. 3, 625ss.

(189) Cf. K. Vechtel, Trinität und Zukunft. Zum Verhältnis von Philosophie und Trinitätstheologie im Denken Wolfhart Pannenbergs, Frankfurt 2001, 109ss; J. A. Martínez Camino, Sobre la teología trinitaria de W. Pannenberg, Revista Catalana de Teología 25 (2000), 289-304; J.-M. Glé, Le retour de l'eschatologie, Recherches de Science Religieuse 84 (1996), 424ss.

(190) Grundzüge der Christologie, 232ss.347; Systematische Theologie, vol. 2, 365ss.

(191) Cf. Christologie und Theologie, 144ss; Systematische Theologie, vol. 1, 337. 
de Dios en su destino no tiene par. Es una acción peculiar y originariamente personalizadora: pone en relación con Dios a aquel hombre en el extremo de su humilde autodistinción del Padre, en la cruz. Lo pone en relación con el Padre como la persona del Hijo, y precisamente así alcanza el hombre Jesús su identidad. Es la obra del Espíritu en la resurrección (192).

Desde el fin proléptico de la historia obrado por el Espíritu en la resurrección de Jesús, se puede ver cómo realiza el Dios de la historia en ella su identidad junto con la identidad del hombre: solo como el "poder del amor" (193). El todopoderoso es el que afirma el ser del otro en su diferencia sin apartarlo de sí: el amor divino se expresa, subraya nuestro autor, cuando el poder del futuro diferencia alguna cosa de él mismo dándole un ser propio, íntegro y consistente y otorgándole la posibilidad de esta manera de tomar parte en el movimiento del amor divino; Dios no tiene unidad ni ser ninguno fuera del movimiento de su amor, por el cual diferencia lo otro de él mismo, vinculándose, simultáneamente, a ello. Con esto el amor se constituye en la respuesta a la pregunta fundamental y fundamentante de la filosofía de por qué existe algo en absoluto y no más bien la nada, en donde el amor fundamenta la existencia (194). El hombre se realiza dejándose admitir en ese modo de la autorrealización de Dios. O, dicho de otra manera, cuando encuentra el ser auténtico de Dios. Solo se realiza en cuanto y como Dios se realiza. Bien entendido, pues, que Dios es el "sujeto" de esa historia común en la que el hombre encuentra su identidad como don en el proceso de su búsqueda de la identidad de Dios. Aquí se puede rastrear por cierto la idea, muy cara a nuestro autor, que "la infinitud de Dios -a diferencia de los seres humanos que permanecen separados unos de otros- va más allá de los límites de los sujetos finitos y de su actuación, de tal modo que le podemos muy bien pensar a Dios como realizándose a sí mismo a través de la actuación de los hombres, a través de su búsqueda y de su hallazgo de la verdadera naturaleza de lo divino a lo largo de la historia de la religión" (195). "Esta condición [que el yo actuante fuera ya desde el principio de su acción idéntico con su destino en sentido pleno, lo cual justamente ha de ser el resultado de su acción] solo se da en el caso de la acción divina: Dios se realiza a sí mismo en el mundo viniendo a él. Para ello se presupone ya su existencia eterna en la comunión del Padre, el Hijo y el Espíritu santo; y la esencia eterna de Dios no necesita perfeccionarse viniendo al mundo. Pero con la creación del mundo la divinidad de Dios, e incluso su existencia, se hacen dependientes de la relación plena del destino de dicho mundo con la presencia del reinado de Dios" (196). Dios se realiza al ser encontrado como él es, es decir, en su alianza con los que sufren la debilidad en el mundo por la causa de su Reino (197).

El sentido de la historia es, pues, para la fe cristiana, el que ha aparecido ya en Jesucristo: el encuentro de la humanidad con Dios. En esta dirección, y en conso-

(192) Cf. Systematische Theologie, vol.1, 337-342; Systematische Theologie, vol. 2, 406ss.

(193) Systematische Theologie, vol.1, 456.

(194) Cf. Systematische Theologie, vol. 1, 456ss; Systematische Theologie, vol. 3, 689ss.

(195) Christologie und Theologie, 143.

(196) Systematische Theologie, vol. 1, 422-423.

(197) Cf. Christologie und Theologie, 143ss. 
nancia con la crítica a una devaluación de la cristología en jesuología (198), nuestro autor apela a la recuperación de la idea de Jesucristo como $\lambda$ ó $\gamma$ o $\varsigma$ del acontecer: "El sentido de la historia en su totalidad nos es desconocido y, sin embargo, se presupone en todas nuestras experiencias e interpretaciones del sentido. El concepto de sentido de la historia equivale al concepto de logos de la filosofía antigua. Se trata de una conclusión a la que se llega si se tiene en cuenta que el concepto de historia se refiere al proceso de la realidad total y tematiza esta realidad bajo el aspecto de la unidad entre ser y tiempo. La vieja fórmula de la encarnación del logos en Jesús de Nazaret debe ser entendida, de forma específica, como anticipación de una estructura de sentido de la historia y de todos sus acontecimientos que, solo al final de la historia, se revelará en la plenitud de su totalidad" (199). Pero este encuentro ha de ir aconteciendo todavía para los hombres de cada época. Y la experiencia de la cruz, de la debilidad de Dios en el mundo, se repite. Y se repite la paciencia amorosa de Dios hasta que el Señor vuelva. Mientras tanto, esta historia humano-divina participa de la misma ambigüedad que caracterizó la pretensión y la cruz de Jesús. Hasta el punto de que la misma realidad de Dios, y con ella la verdad del sentido cristiano de la historia, sigue y seguirá en cuestión hasta el final: la Strittigkeit de la divinidad de Dios la entiende nuestro autor desde el significado de la cruz; desde ahí es posible pensar cómo ante el dolor de este mundo "el momento de su problematicidad (Strittigkeit) en este mundo forma parte también de la divinidad de Dios en esta historia aún no terminada" (200).

Pero de igual manera que la fuerza del Espíritu de Dios se manifestó en la flaqueza de la cruz, así también la presencia del mismo Espíritu de Jesús se hace notar en medio de la ambigüedad de la historia que arranca con nuevo impulso del acontecimiento de Cristo. Sigue siendo la misma historia que Dios ha hecho desde siempre con su creación, y muy en particular la historia en la que Dios sale al encuentro del hombre que le busca: la historia humano-divina (Troeltsch). Pero hay nuevos criterios para encontrar en ella la acción salvadora de Dios. La fe, ahora iluminada por la revelación de Dios en Jesucristo, que incluye ineludiblemente la conciencia de la cruz, de la aparente ausencia del poder de Dios, sigue encontrándose con la realidad de Dios en la historia. A la teología de la historia le corresponde explicitar los criterios de discernimiento que contribuyan, al nivel de la reflexión, a clarificar cómo el poder de Dios actúa en medio de su debilidad en el mundo, mostrando así su realidad a quien le busca.

\subsection{La historia: locus de la revelación}

Para Pannenberg, no hay criterio último de acreditación del lenguaje sobre Dios que no sea el encuentro histórico con la divinidad. Es este encuentro el que constituye el último paso de un "argumento ontológico", por así decir, historizado, al que compete la verificación de la idea de Dios. Verificación en el doble sentido

(198) Cf. A. Schilson, art. Jesuologie, en: W. Kasper (ed.), Lexikon für Theologie und Kirche, vol. 5, Freiburg ${ }^{3} 1996$, 803-804.

(199) W. Pannenberg enjuicia su propia teología, en: M. Fraijó, El sentido de la historia, 278.

(200) Christologie und Theologie, 145; cf. Systematische Theologie, vol. 1, 476ss. 
de mostrar que no se trata de una mera ilusión y de acercar cada vez más esa idea a la realidad a la que remite. La teología ha de presuponer que ese encuentro se da en la historia concreta de las religiones y, en particular, de modo único en la historia del cristianismo.

El encuentro con Dios sucede para el individuo allí donde la experiencia de un determinado acontecimiento de su vida le ilumina de tal manera el conjunto de ella que no puede más que comprenderla como una manifestación del poder que la determina en su integridad haciendo posible la libertad. Naturalmente, el encuentro acontece siempre en el seno de una determinada tradición. La bíblica cuenta expresamente con que la realidad de Dios se muestra y se mostrará en sus actuaciones históricas. Hasta el punto de que, de hecho, y sin perjuicio de la confianza religiosa, para el Pueblo del Dios de la promesa, el poder de su Dios está en juego en los avatares de la historia. Así lo mostraría la diversidad misma de tradiciones que corresponde a la diversidad de experiencias que han propiciado su nacimiento y transformación. El carácter proléptico de la revelación de Dios en Jesucristo se entiende en ese contexto, aunque sea introduciendo en él algo cualitativamente nuevo. De ahí que la "esencia" del cristianismo no pueda confundirse con algo ya dado de una vez por todas: ni siquiera con la predicación o el destino de Jesús. Lo propio del cristianismo -sobre lo cual se ha discutido mucho en este Seminario, sea en su carácter utópico Iglesia/Trinidad o desde lo teológico-fundamental regula fidei/ Dios- está más bien en la tensión fundamental que se muestra en la predicación del Reino y, en su mayor grado, en el acontecimiento de la cruz y de la resurrección. Es esa tensión la que hace del cristianismo una historia abierta "entre la llegada del futuro de Dios en Jesucristo y el futuro de su Reino bajo el signo del Cristo que ha de volver" (201).

La verdad de la revelación cristiana no es, pues, independiente de su historicidad. Es el proceso mismo de la historia del cristianismo el que ha de ser tenido como "mediador" (Vermittlung) del "entonces" de la tradición con el "ahora" de la experiencia del momento (202). De modo que el puente hermenéutico no puede ser el de una "hermenéutica pura", ahistórica, que, con una argumentación "de aplicación", existencial o sobrenaturalista, ignore la eficaz presencia del Dios de Jesucristo en la constitución de todo acontecer (203).

La historia del cristianismo adquiere en esta perspectiva, en cuanto disciplina académica, una función sistemático-práctica que "afecta a toda la teología" (204). Porque trata de cómo dicha historia puede ser comprendida como fruto de la acción del Dios de Jesucristo y, por tanto, como su automanifestación en ella. Es cierto que un acercamiento así de decididamente teológico a la historia tiene en su contra la sensibilidad histórica moderna. En parte por razones comprensibles. Pero Pannenberg no ve cómo se puede renunciar a él sin reconocer al mismo tiempo la "irrealidad" del Dios bíblico (205).

(201) Wissenschaftstheorie 420.

(202) Cf. art. Geschichte, 665.

(203) Cf. Über historische und theologische Hermeneutik, 130s.

(204) Wissenschaftstheorie, 394.

(205) Cf. ibíd., 399. 
Ahora bien, el método de dicho acercamiento puede y debe ser, en su opinión, "descriptivo", no dogmático.

El acontecimiento de Jesucristo es ciertamente el centro de la teología cristiana de la historia. Solo "en conexión" con él y "en el recuerdo" de él puede hacerse una lectura de los acontecimientos de cada época como revelación (206). A primera vista esto parece suponer la introducción de un prejuicio en el acercamiento al acontecer histórico o incluso un dar ya por sentado lo que se quiere rastrear y verificar en él, es decir, la acción de Dios como constitutiva de la historia y, con ello, su automanifestación. Y así sería -concede Pannenberg- si la teología tratara del destino de Jesús como un dato originario, inamoviblemente adquirido. Pero ya sabemos que, según nuestro autor, de lo que se trata es de manejar como hipótesis en cuestión la pretensión de normatividad de la tradición. Eso sí, una hipótesis que merece ser tenida en cuenta tras un estudio de los documentos pertinentes. Que la verdad de la historia y, por tanto, la revelación de Dios, esté anticipadamente presente en Jesucristo es la tesis de la fe cristiana que el teólogo tratará como hipótesis.

Además, "las categorías metodológicas" que la misma tradición bíblica pone en manos de la teología para el trabajo de acreditación de su hipótesis, como son las de "pueblo de Dios", "elección", "juicio" y "alianza" son de "carácter experiencial", es decir, que tienden a establecer la relación entre el lenguaje religioso de la tradición y la experiencia histórica de cada momento del proceso traditivo (207).

"Pueblo de Dios" es la categoría fundamental de la teología de la historia (208). En referencia a ella se entienden las otras. No es primariamente el individuo el que tanto en el Antiguo como en el Nuevo Testamento es objeto de la elección divina. Sin olvidar el lugar insustituible de los individuos, elegidos también en y para el pueblo, es necesario recordar cómo el contenido de la elección no hace referencia al individuo aislado, sino a su destino social. El Pueblo es elegido para disfrutar de un orden social "verdadero". La "alianza" establece las condiciones de la iniciativa divina de elección. Esta iniciativa se asocia a una experiencia histórica de liberación que funda la identidad colectiva en cuanto hace posible una percepción unitaria de los eventos de la historia como constante punto de referencia. La infidelidad a la alianza conlleva experiencias negativas contrarias a los fines pretendidos por Dios con su elección; de modo que dichas experiencias son interpretadas como otro modo de su actuación por el que Dios reacciona a la conducta opuesta a su voluntad salvadora.

Pannenberg cree que la historia del cristianismo puede y debe ser interpretada, en dichas categorías, como una "ampliación de la historia de elección de Israel" a todos los pueblos. Hay bases suficientes para ello en el Nuevo Testamento y, por otro lado, la historia misma de las "culturas" que se han sucedido en el ámbito de influencia del cristianismo parece apuntar a este como clave de su interpretación (209).

El "nuevo pueblo de Dios" está llamado a integrar a todos los pueblos de la tierra en uno solo. A ese único pueblo de Dios es al que el Evangelio anuncia la

(206) Cf. ibíd., 296ss

(207) Die Bestimmung des Menschen, Göttingen 1978, 92ss (El destino del hombre, Salamanca 1981).

(208) Cf. sobre todo el capítulo quinto de Systematische Theologie, vol. 3, 469-568.

(209) Cf. Die Bestimmung des Menschen, 84ss. 
llegada del Reino. Este abarca a todos los pueblos en todos sus aspectos, incluida la dimensión de su constitución social, la política. De modo que "el pueblo de Dios cristiano ha sido elegido para existir en este mundo como la comunidad escatológica del Dios de Israel. Da testimonio ya ahora de su futuro reinado sobre toda la creación y sobre toda la humanidad" (210). La Iglesia es "instrumento y sacramento" de este futuro Pueblo único de Dios. No se identifica, pues, con él. Pero solo gracias a su presencia y a su anuncio también el orden social presente es referido simbólicamente al Reino de Dios. Por eso la legitimación cristiana del orden social es siempre al mismo tiempo su crítica (211).

Una historia leída como historia del Dios que elige para salvar, también en su juicio, tiene "carácter de revelación", a la luz de su fin aparecido en Jesucristo. "Ante el cuestionamiento moderno de la fe en Dios [...] la idea de que Dios se revela a sí mismo le pone de nuevo en relación con el mundo que se aparta de Él cuando se piensa en una historia que, a través de juicio y de reconciliación, transforma este mundo en el lugar del reinado de Dios y de la revelación definitiva de su gloria gracias a la realización escatológica de su voluntad creadora" (212). Es esta historia reveladora la que permite el acceso definitivo a Dios mientras caminamos en la fe. En ella se encuentra una y otra vez asumida y superada desde siempre en el cristiano la idea abstracta de Dios, que el comparte con la inmensa mayoría de la Humanidad.

\section{CONCLUSIONES}

En este Seminario, luego de las ponencias de orden filosófico (Alejandro Vigo y Mariano de la Maza) quedó lanzado el desafío a la teología de hacerse cargo de las preguntas ahí planteadas: habrá pues que elaborar una hermenéutica teológica que desarrolle las interrogantes filosóficas (213), si es que no se quiere establecer un cierto hiato entre la confesión en el Dios creador, redentor y consumador y las preguntas que nacen del pensar el mundo y la historia (o si se quiere, el ser) desde la filosofía. Aquí estaría en juego, por ocupar un término de nuestro autor, la misión de la Iglesia a cuyo servicio, como ciencia de Dios, está la teología (214).

Con respecto a esto último pensamos que, a modo de ejemplo, repensar la relación Logos-logos es un camino que ofrece valiosas prospectivas.

En la exposición que en este Seminario realizó Alejandro Vigo, se hizo referencia a la interpretación que actualmente realizaba J. Grondin del pensamiento de

(210) Ibíd., 108.

(211) Cf. Systematische Theologie, vol. 3, 523ss.

(212) Offenbarung als Geschichte, Vs; cf. la reciente publicación de artículos sobre ética de nuestro autor en, Beiträge zur Ethik, Göttingen 2004.

(213) Cf. M. Ferraris, La hermenéutica, Madrid 2004; I.U. Dalferth-Ph. Stoellger, Hermeneutik in der Diskussion. Orientierungsversuche in einem unübersichtlichen Gebiet, Theologische Rundschau 69 (2004), 30-74; M. Jung, Hermeneutik; R. Voderholzer, Hermeneutik. Von der Schrift bis Schleiermacher (Handbuch der Dogmengeschichte 3c/ Tl 1), Freiburg 2003.

(214) Cf. las valiosas pistas y criterios que ofrecen, S. Wiedenhofer, art. Hermeneutik, III: Systematisch-theologisch, en: W. Kasper (ed.), Lexikon für Theologie und Kirche, vol. 5, Freiburg 31996, 67; H. Hoping, Gottes Offenbarung und die Frage ihrer Verstehbarkeit, Theologische Literaturzeitung 129 (2004), 3-24. 
Gadamer en relación al logos interior. Vigo también señalaba cómo este discípulo de Gadamer presentaba esta interpretación como una tarea relevante de la hermenéutica actual. Nosotros pensamos que una de las perspectivas que permiten pensar en el futuro en la relevancia del planteo teológico de Pannenberg en el diálogo con la filosofía, radica, entre otras, en su elaboración de la temática del logos, al cual ya hemos hecho referencia y que modula varios de los temas claves que hemos presentado en esta exposición (215).

Grondin (216) piensa que solo un nuevo historismo podría concluir que finalmente todo es relativo, y habrá que liberarse de esta posición si se pretende acercarse más a la verdad. Uno de los logros más relevantes de la hermenéutica contemporánea fue, a su juicio, el haber indicado al pensamiento filosófico el camino fuera del marco de ese planteamiento tan oblicuo de la pregunta, después de que la filosofía desde Hegel se hubiera quedado encallada en el problema del historismo. Esto queda señalado en la diferenciación hermenéutica entre verdad y método. La verdad existe también más acá o más allá del estrecho círculo de lo que se puede someter a método. Evidentemente, más allá del método también hay mucha insensatez. ¿Se exige también aquí un "criterio" para distinguir entre verdadero y falso? ¿Qué se entiende por criterio? ¿Acaso un medio formal y no engañoso que podamos aplicar cómodamente e indistintamente a todas las situaciones? De este modo no se superaría el historismo. El método todavía desplaza al alma. Lo que no se percibe es que el diálogo que nunca dejamos de ser puede aceptarlo todo y que al mismo tiempo experimenta la verdad en sí mismo.

Esta capacidad de crítica y de razón tiene su sede en el verbum interius (Agustín), en el monólogo que cualquier persona es para sí misma. Cabe señalar que la

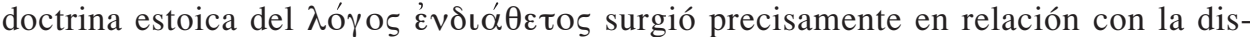
cusión en torno a lo específico de la especie humana. No el lenguaje o el logos exterior distinguiría al ser humano del animal, porque también los animales son capaces de emitir señales acústicas. Lo que nos distingue es únicamente que detrás de la voz se desarrolla una reflexión interior. Ella nos permite ponderar las perspectivas que se nos ofrecen una frente a otra y distanciarnos críticamente de ellas. El ser humano no está totalmente a la merced de sus instintos o de los sonidos en circulación en cualquier momento. Lo que le libera a un posible ser-humano es el espacio de libertad del logos interior, el tema primario de la hermenéutica, como subraya Grondin, que desde la antigüedad se llama y promete razón.

Nosotros creemos que es posible un tránsito fructífero de esta intuición gadameriano-agustiniana del logos interior que ha rescatado actualmente Grondin para la reflexión hermenéutica, hacia la teología del logos que plantea Pannenberg (217)

(215) Cf. supra 4.3

(216) Cf. J. Grondin, Introducción a la hermenéutica filosófica, Barcelona 2002, sobre todo 19-41.157178; id., Der Sinn für Hermeneutik, Darmstadt 1994, 1-70.

(217) Cf. Systematische Theologie, vol. 2, 330ss; Theologie und Philosophie, 90ss; Sinnerfahrung, Religion und Gottesfrage, 101-113, sobre todo 112-113: "el cristianismo reconoce que en Jesús de Nazaret el logos divino se ha hecho hombre, en quien todas las cosas tienen su existencia [Bestand]. Logos se llama lo mismo "sentido" que "palabra", y la relación del pensamiento veterotestamentario de la palabra divina con el concepto de logos griego dice nada menos, que la estructura de sentido [Sinnzusammenhang] que abarca toda la creación y la historia hasta su consumación escatológica se ha manifestado en Jesucristo" (113). 
desde las coordenadas que establece en la cristología entre lo universal y lo concreto. Además este contrapunto le podrá ofrecer a la hermenéutica pannenbergiana una base aún más sólida para subrayar la unidad (al interior de su esquema de identidaddiferencia) entre idea y realidad de Dios.

Como ya hemos señalado, según Pannenberg, la significación constitutiva de la temática religiosa para el ser hombre del hombre se halla estrechamente ligada al hecho de que los seres humanos son seres dotados de conocimiento y de autoconciencia. El hombre distingue de él mismo las cosas de su mundo y las cosas entre sí, también se distingue a sí mismo de las otras cosas y seres con los que se sabe relacionado. Al realizar tal distinción, capta las cosas y seres como finitos mediante su distinción de lo otro concreto. Pero en la idea de lo finito se halla también implicada, al menos implícitamente la de lo infinito. Por eso, el conocimiento humano es, según nuestro autor, un conocimiento que trasciende la finitud de sus objetos. En la comprensión de los objetos finitos en su particularidad se halla siempre incluida la conciencia de lo infinito como condición del conocimiento y de la existencia de tales objetos. Por ello el hombre, en lo que es una de las tesis clave de nuestra exposición, ya en su constitución existencial como ser consciente, se encuentra según Pannenberg definido como un ser religioso.

Pues bien, en esta constitución de la vida consciente se halla presente de un modo especial el Logos, que, en cuanto principio generado de la particularidad, funda y gobierna la singularidad propia de cada creatura. El hombre, en cuanto ser consciente de sí mismo en relación con lo otro, convierte en objeto de su conciencia ese carácter distinto de cada cosa y ser en su alteridad, mientras que tal carácter solo determina fácticamente a todo el resto de los seres creados. En este sentido, en su vida consciente, el hombre se halla de un modo específico en posesión del Logos que gobierna todo lo creado.

Se trata, según Pannenberg, de una tesis que no se encuentra únicamente en la tradición de la filosofía griega del Logos. También según Juan 1, 4b y 1, 9, el Logos es la "luz" de los hombres y, por tanto, los hombres participan de un modo especial en el Logos, al que, de acuerdo con Juan 1, 3, todas las cosas le deben su existencia (la vida). Con razón convirtió Atanasio la participación en el Logos concedida al hombre en la creación en punto de partida de su teología de la encarnación del Logos. Sin tal supuesto, y este es un aspecto estructural de la lógica del planteo pannenbergiano, la encarnación del Logos sería algo ajeno a la naturaleza del hombre. No podría en ese caso decirse de la encarnación del Logos: "Vino a los suyos" (Juan 1, 11). Es cierto que inmediatamente a continuación se añade que los suyos no le recibieron, pero lo inaudito de esta realidad se encuentra precisamente en que los hombres pertenecen por creación al Logos, por lo que son "los suyos". La interpretación de esta específica participación del hombre en el Logos como actividad del conocimiento humano que distingue y relaciona lo distinguido, presupone teológicamente lo ya dicho en nuestra exposición sobre la autodiferenciación de Jesús con respecto al Padre, constitutiva de su filiación. En la doctrina de la creación se utiliza ya esta autodiferenciación con respecto al Padre como clave para comprender la función cosmológica del Logos como mediador de la creación. La afirmación de la fundamental importancia de esta realidad es la tarea que Pannenberg pretende comprobar y profundizar en la cristología, y mostrar también su repercusión en el dogma. 
Las críticas que ha despertado el planteo hermenéutico de Pannenberg ya son legión: que supone una cierta arrogancia de la religión cristiana de cara al diálogo interreligioso; que su sistema cae en el trilema de Münchhausen; que devalúa la monarquía del Padre; que representa una posición oscilante entre una clara opción por la positividad inmanente de Dios y expresiones que hablan, al mismo tiempo, de potencialización condicionada de Dios, si bien bajo el presupuesto de la positividad y libertad divinas; que subyace un hiato de cuño kantiano entre idea y realidad de Dios; el excesivo influjo de Hegel; los peligros que implica un sistema teológico bien establecido frente a la sensibilidad teológica por la pluralidad de contextos para decir hoy en día Dios, contextos limitados, determinados por microhistorias, marcados por el individualismo y el pluralismo; la revisión constante de los macroconceptos de verdad, universalidad, historicidad, totalidad y realidad; que exige a una teología como la de Pannenberg una constante recontextualización, la que a veces no es permitida por sus rígidos presupuestos epistemológicos; la necesidad de repensar el axioma Dios como la realidad que todo lo determina, desde una reflexión trascendental de la libertad; su abstención en el uso de la analogía y su temprana adhesión a Duns Scoto en este sentido; un cierto corsé formalista que supondrían los criterios científicos de hipótesis y verificabilidad (sobre todo desde la publicación en 1973 de su Teoría de la ciencia y teología) para interpretar la revelación, etc.

Sin poder comentar la pertinencia de cada una de las críticas, que por cierto dan que pensar (y no necesariamente porque los argumentos de estas críticas sean del todo convincentes, sino por el hecho que también nos muestran la pluralidad de presupuestos epistemológicos y filosóficos que influyen en la toma de postura hermenéutica, que viene dada por la pregunta por quién interpreta, qué es lo interpretado y su relación), estamos convencidos que el planteo hermenéutico de Pannenberg invita a transitar por el camino de las preguntas fundamentales de la hermenéutica teológica desde su "pasión por la argumentación", como él mismo dice, a partir de un mínimo irrenunciable sobre el cual no se puede, a nuestro juicio, volver atrás: formular las relaciones entre Dios y hombre en las coordenadas de identidad y diferencia en el contexto de la historia (y su estatuto ontológico), lo que permite criterios de verificación de las hipótesis teológicas, en los cuales el Pueblo de Dios juega un rol capital.

Por último, quizá no exista mejor forma de probar la profundidad de la identidad y relevancia de un planteo teológico, que contrastar su núcleo teológico con la relevancia que le exige la filosofía (218). Así por ejemplo, una de las obras filosóficas que en nuestro tiempo se ha decidido a dialogar de forma profunda con la teología es la de Franz von Kutschera (219): ¿qué respuestas puede ofrecer la reli-

(218) Así por ejemplo, M. Jung propone una serie de temas que deberían ser abordados por una auténtica hermenéutica que se enfrente a las preguntas profundas del pensar y, no solo al análisis: la diferencia entre sentido y lleno de sentido, un pensamiento inclusivo de las diferencias (sobre todo las provenientes de las ciencias del espíritu y la naturaleza), la interdisciplinariedad, el carácter pragmático de la hermenéutica, etc. (cf. Hermeneutik, sobre todo, 7-27.133-160).

(219) Cf. sus obras, Vernunft und Glaube, Berlin-New York 1990 y Die großen Fragen. Philosophischtheologische Gedanken, Berlin 2000. Otro ejemplo de diálogo con la teología, y en este caso con Pannenberg, es el que propone el filósofo tubingués L. Oeing-Hanhoff, Die Krise des Gottesbegriffs. W. Pannenbergs zum 50. Geburstag, Theologische Quartalschrift 159 (1979), 285-303. De provecho resulta también leer las reflexiones de B. Puntel en relación al tema (con alusión al planteo de Pannenberg), La teología cristiana ante la filosofía contemporánea, Stromata 57 (2001), 119-151. 
gión a las preguntas existenciales que nacen de la apertura al sentido de la existencia humana en sus condiciones actuales?, ¿pueden otorgar estas respuestas una orientación a la propia vida, y no solo solucionar problemas académicos?, ¿cómo se puede pensar la resurrección de Jesucristo como aspiración humana -y creacional- fundamental?, ¿de qué manera el Dios de Jesucristo, el Padre, en su invitación a tomar parte en su amor a todos los hombres y con ello a coparticipar en la redención del mundo, se transforma en una invitación a la razón a pensar en sus límites?, ¿de qué forma nuestro llamado a la santidad es un llamado a la comunión con Dios en su amor y así una exigencia a la misericordia con el hermano, de tal manera que ahí se revelen las preguntas que nacen de la ética abierta a la pregunta por el sentido? (220) La hermenéutica teológica debe transitar por estas peticiones de la razón moderna, no como un dictado, sino como un deber inherente a su misión.

\section{RESUMEN}

En el presente artículo se pretende señalar cómo Pannenberg desarrolla una hermenéutica teológica que, en diálogo creativo con los desarrollos más importantes de esta ciencia filosófica del siglo XX, ha analizado la categoría de "totalidad de sentido" como ámbito de inserción para la idea de Dios en el mundo contemporáneo. Pannenberg señala de qué manera la religión cristiana conlleva en Jesucristo una "anticipación" de la totalidad de sentido en la historia.

\section{ABSTRACT}

This article presents the way Pannenberg develops a theological hermeneutics, which analyzes the category of "fullness of sense" as an appropiarite domain for the insertion of the notion of God in the modern world. This is done by engaging theological hermeneutics in a creative dialogue with the most important developments of philosophical science in the $20^{\text {th }}$ century. This leads Pannenberg to claim that with Jesus Christ, Christianity brings along an "anticipation" of the fullness of sense in history. 